\title{
Thermal decomposition of the amino acids glycine, cysteine, aspartic acid, asparagine, glutamic acid, glutamine, arginine and histidine
}

\author{
Ingrid M. Weiss ${ }^{1,2^{*}}$, Christina Muth², Robert Drumm² and Helmut O. K. Kirchner ${ }^{2}$
}

\begin{abstract}
Background: The pathways of thermal instability of amino acids have been unknown. New mass spectrometric data allow unequivocal quantitative identification of the decomposition products.

Results: Calorimetry, thermogravimetry and mass spectrometry were used to follow the thermal decomposition of the eight amino acids $\mathrm{G}, \mathrm{C}, \mathrm{D}, \mathrm{N}, \mathrm{E}, \mathrm{Q}, \mathrm{R}$ and $\mathrm{H}$ between $185^{\circ} \mathrm{C}$ and $280^{\circ} \mathrm{C}$. Endothermic heats of decomposition between 72 and $151 \mathrm{~kJ} / \mathrm{mol}$ are needed to form 12 to $70 \%$ volatile products. This process is neither melting nor sublimation. With exception of cysteine they emit mainly $\mathrm{H}_{2} \mathrm{O}$, some $\mathrm{NH}_{3}$ and no $\mathrm{CO}_{2}$. Cysteine produces $\mathrm{CO}_{2}$ and little else. The reactions are described by polynomials, $\mathrm{AA} \longrightarrow a \mathrm{NH}_{3}+b \mathrm{H}_{2} \mathrm{O}+c \mathrm{CO}_{2}+d \mathrm{H}_{2} \mathrm{~S}+$ e residue, with integer or half integer coefficients. The solid monomolecular residues are rich in peptide bonds.

Conclusions: Eight of the 20 standard amino acids decompose at well-defined, characteristic temperatures, in contrast to commonly accepted knowledge. Products of decomposition are simple. The novel quantitative results emphasize the impact of water and cyclic condensates with peptide bonds and put constraints on hypotheses of the origin, state and stability of amino acids in the range between $200^{\circ} \mathrm{C}$ and $300^{\circ} \mathrm{C}$.
\end{abstract}

Keywords: Amino acid, Thermal analysis, Quantitative mass spectrometry

\section{Background}

The so-called 20 standard amino acids are fundamental building blocks of living systems [1]. They are usually obtained in solid form from aqueous solution by evaporation of the solvent [2]. Most of today's knowledge about amino acids is therefore limited to the temperature and pressure range of liquid water. A huge number of physical and chemical data were unequivocally established - at least for the 20 standard amino acids [3]. Thermal stability or instability of amino acids, however, is one of the few fields which remains speculative until today, at least to some extent. One major reason for deficiencies in that respect could be that data aquisition is

${ }^{*}$ Correspondence: ingrid.weiss@bio.uni-stuttgart.de

'Institute of Biomaterials and Biomolecular Systems, University of Stuttgart, Pfaffenwaldring 57, D-70569 Stuttgart, Germany

${ }^{2}$ INM-Leibniz Institute for New Materials, Campus D2 2, D-66123 Saarbruecken, Germany usually performed without analyzing the entire system, where liquid amino acids and decomposition products, as well as their respective gas phases must be taken into account. We used a commercial thermal analysis system with a direct transfer line to a mass spectrometer for characterizing the melting or decomposition process of amino acids under inert atmosphere in the temperature range between $323-593 \mathrm{~K}$ and detection of masses between $1-199 \mathrm{Da}$ in the vapour phase. Mass analysis was calibrated with respect to $\mathrm{NH}_{3}, \mathrm{H}_{2} \mathrm{O}$ and $\mathrm{CO}_{2}$ by searching for suitable reference substances, with the goal to identify whether or not there is a common underlying principle of melting - solidification and/or sublimation - desublimation and/or irreversible decomposition for amino acids. Previous reports missed the quantitative identification of gaseous products. The broader implication of this general relationship between amino acids and their condensation products is that amino acids 
might have been synthesized under prebiological conditions on earth or deposited on earth from interstellar space, where they have been found [4]. Robustness of amino acids against extreme conditions is required for early occurrence, but little is known about their nonbiological thermal destruction. There is hope that one might learn something about the molecules needed in synthesis from the products found in decomposition. Our experimental approach is not biochemical, it is merely thermochemical.

\section{Methods}

\section{DSC, TGA, QMS}

Altogether 200 samples of amino acids of at least $99.99 \%$ purity from Sigma-Aldrich were tested in a Simultaneous Thermal Analysis apparatus STA 449 Jupiter (Netzsch, Selb, Germany) coupled with Mass spectrometer QMS 403C Aëolos (Netzsch). Specimens of typically $10 \mathrm{mg}$ weight in $\mathrm{Al}$ cans were evacuated and then heated at $5 \mathrm{~K} / \mathrm{min}$ in argon flow. Differential scanning calorimetry (DSC) and thermal gravimetric analysis/thermogravimetry (TGA, TG), as well as quantitative mass spectrometry (QMS) outputs were smoothed to obtain the data of "Raw data" section. The mass spectrometer scanned 290 times between $30{ }^{\circ} \mathrm{C}$ and $320{ }^{\circ} \mathrm{C}$, i.e. at every single degree in $1 \mathrm{Da}$ steps between $1 \mathrm{Da}$ and $100 \mathrm{Da}$. Alltogether, $290 \times 100 \times 200=5.8$ million data points were analyzed.

\section{Visuals}

A MPA120 EZ-Melt Automated Melting Point Apparatus (Stanford Research Systems, Sunnyvale, CA, U.S.A.) equipped with a CAMCORDER GZ-EX210 (JVC, Bad Vilbel, Germany) was used for the optical observations. The same heating rate of $5 \mathrm{~K} / \mathrm{min}$ was employed, but without inert gas protection. Screen shot images were extracted from continuous videos registered from 160 to $320^{\circ} \mathrm{C}$, for all amino acids significant moments are shown in "Results".

\section{Results}

\section{Raw data}

Although we examined all 20 amino acids, we report results for those eight of them, for which the sum of the volatile gases, $\mathrm{NH}_{3}, \mathrm{H}_{2} \mathrm{O}, \mathrm{CO}_{2}$ and $\mathrm{H}_{2} \mathrm{~S}$, matched the mass loss registered by thermogravimetry (TG). Only if both, the mass and the enthalpy balance match precisely, as in our case $\pm 5 \mathrm{Da}$ (see Table 1 for details), it is possible to take these data as a proof for the correctness of the proposed reaction. This is the reason why only 8 of the 20 amino acids are reported here. Only for them we know for sure, how they decompose. For each amino acid we show the skeleton structure, the optical observations, the DSC signal in red and the TG signal in black, as well as the ion currents for important channels, quantitatively significant are only the $17 \mathrm{Da}\left(\mathrm{NH}_{3}\right.$, green lines), $18 \mathrm{Da}$ $\left(\mathrm{H}_{2} \mathrm{O}\right.$, blue lines), and $44 \mathrm{Da}\left(\mathrm{CO}_{2}\right.$, grey lines) signals. The logarithmic scale overemphasizes the molecular weights. The DSC data are given in W/g, the TG data in \%. The QMS data are ion currents $[\mathrm{A}]$ per sample. All data are summarized in Fig. 1 for glycine, Fig. 2 for cysteine, Fig. 3 for aspartic adic, Fig. 4 for asparagine, Fig. 5 for glutamic acid, Fig. 6 for glutamine, Fig. 7 for arginine, and Fig. 8 for histidine.

Glycine, Gly, G

$\mathrm{C}_{2} \mathrm{H}_{5} \mathrm{NO}_{2}, 75 \mathrm{Da}, \mathrm{H}_{\mathrm{f}}=-528 \mathrm{~kJ} / \mathrm{mol}$

\section{Cysteine, Cys, C}

$\mathrm{C}_{3} \mathrm{H}_{7} \mathrm{NO}_{2} \mathrm{~S}, 121 \mathrm{Da}, \mathrm{H}_{\mathrm{f}}=-534 \mathrm{~kJ} / \mathrm{mol}$

Aspartic acid, Asp, D

$\mathrm{C}_{4} \mathrm{H}_{7} \mathrm{NO}_{4}, 133 \mathrm{Da}, \mathrm{H}_{\mathrm{f}}=-973 \mathrm{~kJ} / \mathrm{mol}$

Asparagine, Asn, $\mathrm{N}$

$\mathrm{C}_{4} \mathrm{H}_{8} \mathrm{~N}_{2} \mathrm{O}_{3}, 132 \mathrm{Da}, \mathrm{H}_{\mathrm{f}}=-789 \mathrm{~kJ} / \mathrm{mol}$

\section{Glutamic acid, Glu, E}

$\mathrm{C}_{5} \mathrm{H}_{9} \mathrm{NO}_{4}, 147 \mathrm{Da}, \mathrm{H}_{\mathrm{f}}=-1097 \mathrm{~kJ} / \mathrm{mol}$

Glutamine, Gln, $Q$

$\mathrm{C}_{5} \mathrm{H}_{10} \mathrm{~N}_{2} \mathrm{O}_{3}, 146 \mathrm{Da}, \mathrm{H}_{\mathrm{f}}=-826 \mathrm{~kJ} / \mathrm{mol}$

Arginine, Arg, $R$

$\mathrm{C}_{6} \mathrm{H}_{14} \mathrm{~N}_{4} \mathrm{O}_{2}, 174 \mathrm{Da}, \mathrm{H}_{\mathrm{f}}=-623 \mathrm{~kJ} / \mathrm{mol}$

Histidine, His, $\boldsymbol{H}$

$\mathrm{C}_{6} \mathrm{H}_{9} \mathrm{~N}_{3} \mathrm{O}_{2}, 155 \mathrm{Da}, \mathrm{H}_{\mathrm{f}}=-467 \mathrm{~kJ} / \mathrm{mol}$

The DSC, TGA and QMS curves share one essential feature: In DSC there are peaks at a certain temperature $\mathrm{T}_{\text {peak }}$ for each amino acid, at the same temperatures they are accompanied by drops in TGA and QMS peaks. The simple fact that the DSC and QMS signals coincide in bell shaped peaks with the TGA drop proves that essentially one simple decomposition process takes place, there is not a spectrum of decomposition temperatures, as there would be for proteins. Qualitatively this proves that the process observed is neither melting nor sublimation (as claimed in the literature [5]). The observed process is decomposition, none of the eight amino acids exists in liquid form. The optical observations, not obtained under vacuum but under some air access, are informative nevertheless. Solid/liquid transitions, with the liquid boiling heavily, coincide with the peak temperatures for Gly, Cys, Gln, Glu, Arg and His. Only for Asn and Asp there are solid/solid transformations at the peak temperatures. For Asn there is liquification at $280{ }^{\circ} \mathrm{C}$, Asp stays solid up to $320^{\circ} \mathrm{C}$. 


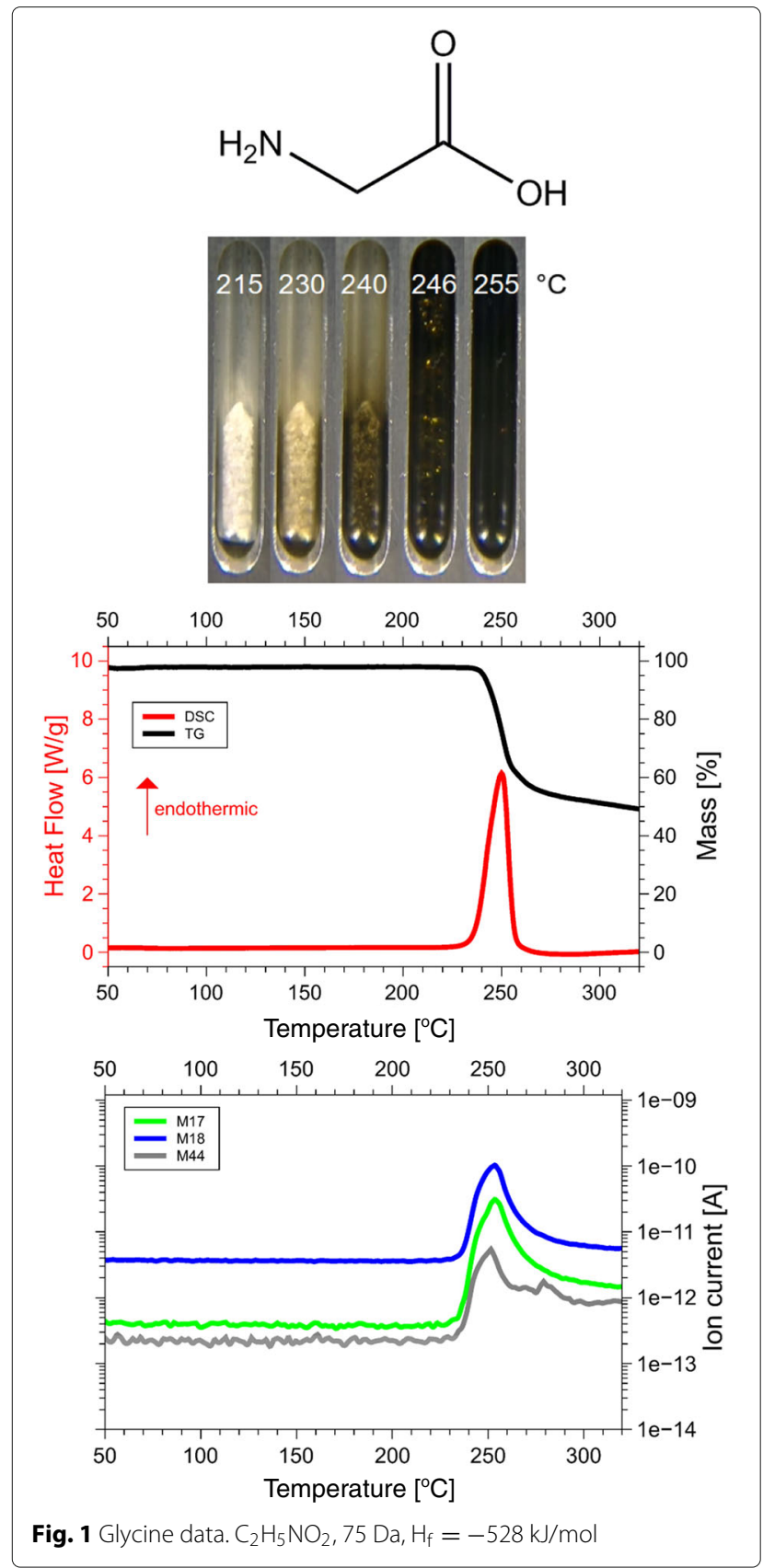

\section{Calibration and quantitative mass spectrometry}

The DSC signals have the dimension of specific power $[\mathrm{W} / \mathrm{g}]$, the QMS ones are ion currents of the order of pA. Integration over time, or, equivalently, temperature, gives the peak areas, which are specific energies $[\mathrm{J} / \mathrm{g}]$ and ionic charges, of the order of $\mathrm{pC}$. Reduction from specimen weights, typically $10 \mathrm{mg}$, to mol values is trivial. In absolute terms the ion currents and ionic charges are meaningless, because equipment dependent, calibration is needed. Only one reliable calibration substance was available, sodium

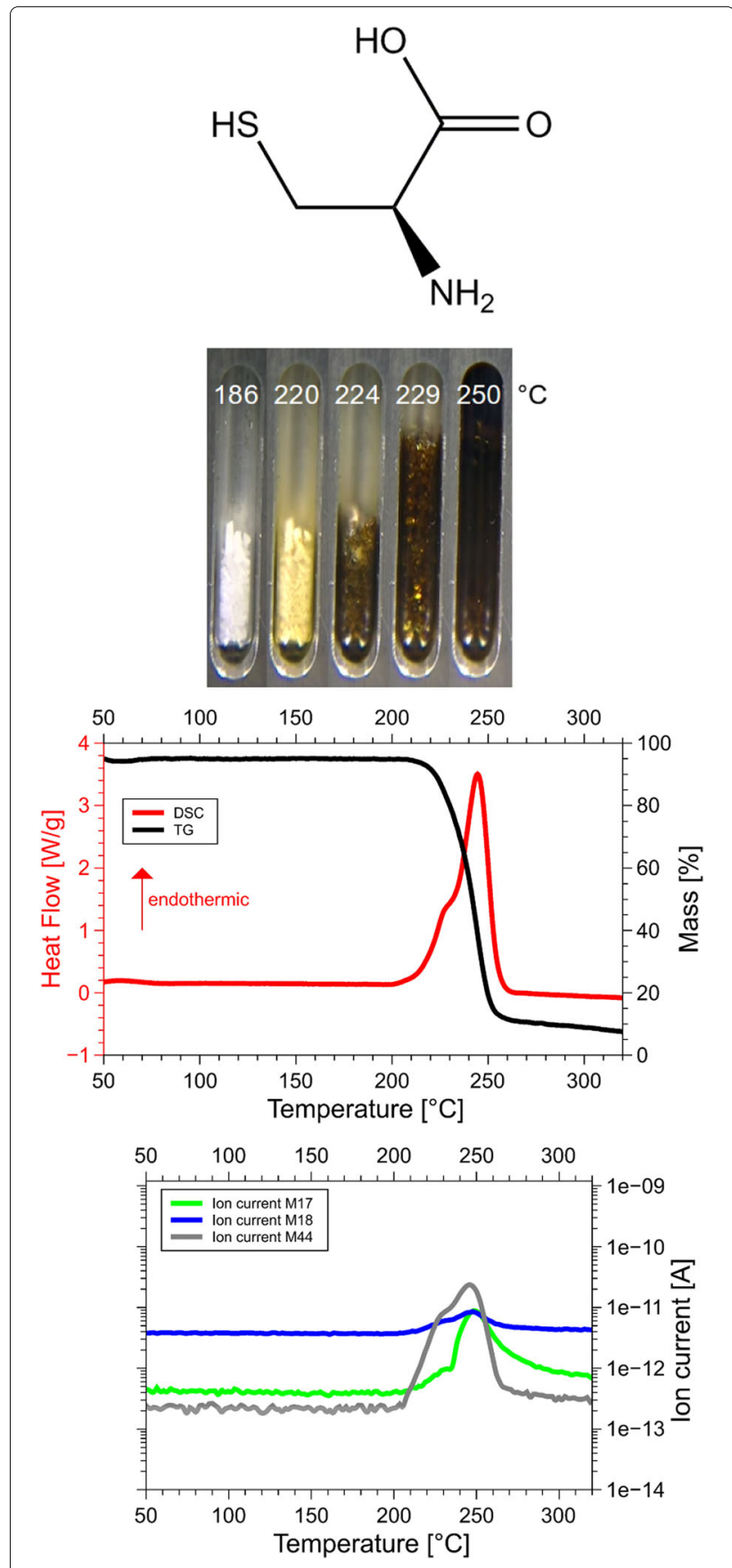

Fig. 2 Cysteine data. $\mathrm{C}_{3} \mathrm{H}_{7} \mathrm{NO}_{2} \mathrm{~S}, 121 \mathrm{Da}, \mathrm{H}_{\mathrm{f}}=-534 \mathrm{~kJ} / \mathrm{mol}$

bicarbonate $\left(\mathrm{NaHCO}_{3}\right)=\mathrm{X} 1$. It decomposes upon heating, $2 \mathrm{NaHCO}_{3} \longrightarrow \mathrm{Na}_{2} \mathrm{CO}_{3}+\mathrm{CO}_{2}+\mathrm{H}_{2} \mathrm{O}$. The $\frac{1}{2} \mathrm{CO}_{2}$ $\mathrm{mol} / \mathrm{mol} \mathrm{NaHCO}_{3}$ and $\frac{1}{2} \mathrm{H}_{2} \mathrm{O} \mathrm{mol} / \mathrm{mol} \mathrm{NaHCO}_{3}$ lines were quantitatively repeatable over months, in terms of $\mathrm{pC} / \mathrm{mol} \mathrm{CO}_{2}$ and $\mathrm{pC} / \mathrm{mol} \mathrm{H}_{2} \mathrm{O}$. They served to identify $1 \mathrm{~mol} \mathrm{CO}_{2} / \mathrm{mol} \mathrm{Cys}$ and $\frac{1}{2} \mathrm{~mol} \mathrm{H}_{2} \mathrm{O} / \mathrm{mol} \mathrm{Q}$ beyond any doubt. In the absence of primary $\mathrm{NH}_{3}$ calibration we 


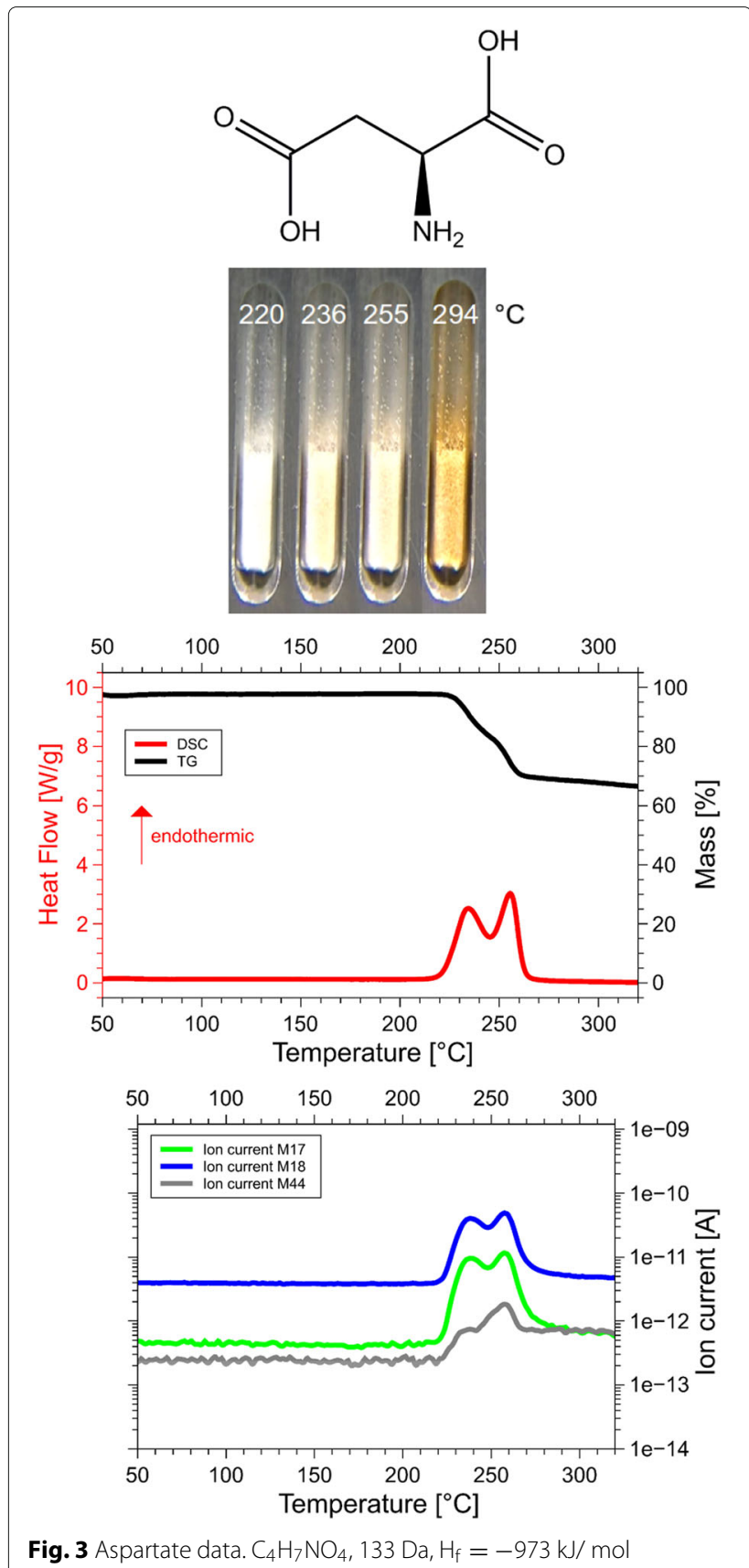

Fig. 3 Aspartate data. $\mathrm{C}_{4} \mathrm{H}_{7} \mathrm{NO}_{4}, 133 \mathrm{Da}, \mathrm{H}_{\mathrm{f}}=-973 \mathrm{~kJ} / \mathrm{mol}$

had to resort to secondary substances, glutamine, aspartic acid and asparagine, which retained stable $\mathrm{NH}_{3}$ and

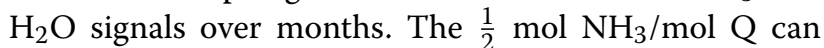
only come from the glutamine dimer, which implies that also the $\mathrm{H}_{2} \mathrm{O}$ signal from glutamine corresponds to $\frac{1}{2}$ $\mathrm{mol} \mathrm{H}_{2} \mathrm{O} / \mathrm{mol} \mathrm{Q}$. For the other two, the correspondence between $1 \mathrm{~mol} \mathrm{H}_{2} \mathrm{O}$ and $1 \mathrm{~mol} \mathrm{NH}_{3}$ is convincing. Thus we had four consistent reference points: $\frac{1}{2} \mathrm{~mol} \mathrm{H}_{2} \mathrm{O}$ and $\frac{1}{2} \mathrm{~mol} \mathrm{CO}_{2}$ from $\mathrm{NaHCO}_{3}$, and $\frac{1}{2} \mathrm{~mol} \mathrm{NH}_{3}$ from glu-

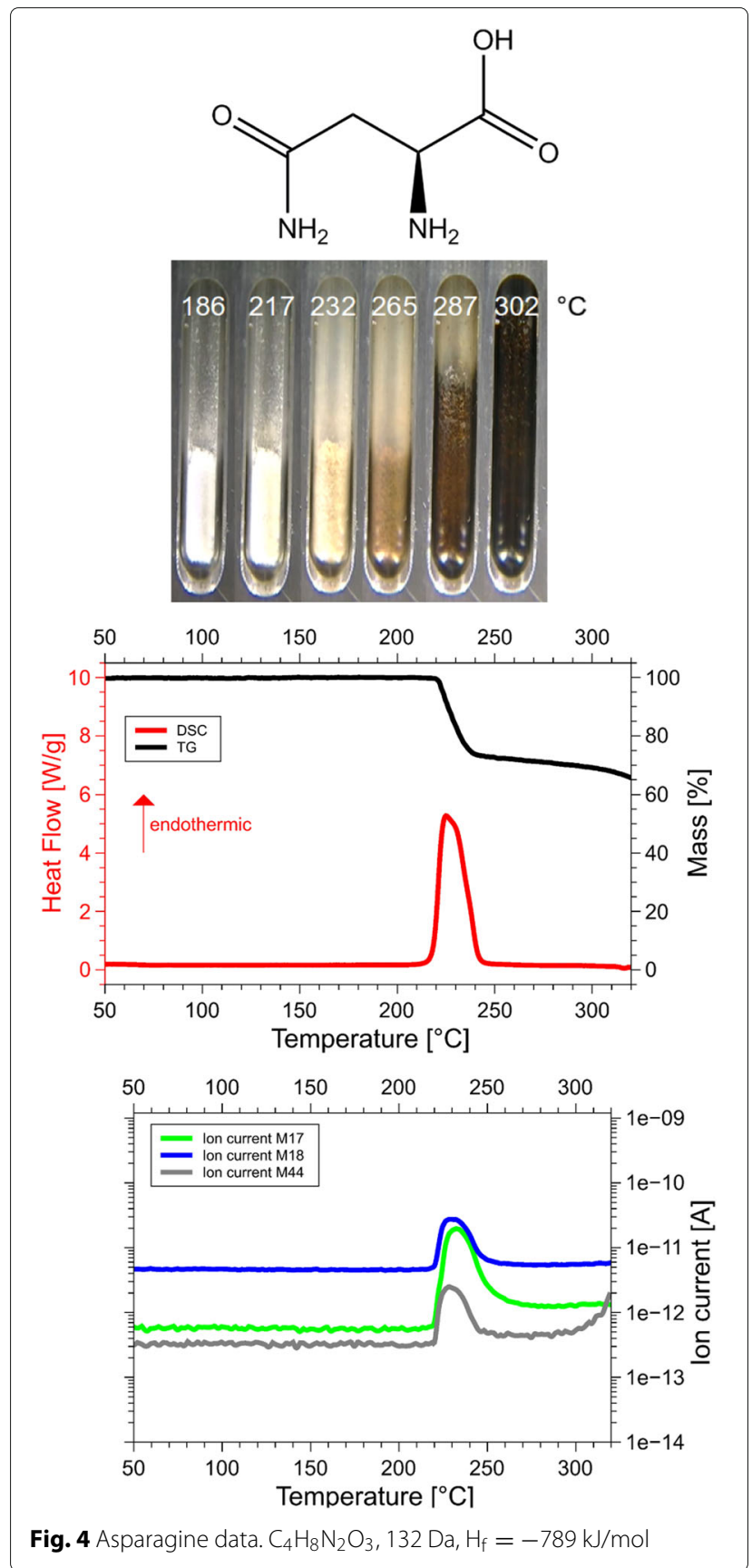

tamine, and $1 \mathrm{~mol} \mathrm{NH}_{3}$ from Asparagine. For each amino acid sample, the ion current is measured individually in each mass channel between 1 and $100 \mathrm{Da}$ in 1 Da intervals. Integration over time (and temperature) gives for each mass the ion charge per mol AA, [C/molAA], and with the four calibrations the final values of mol/molAA. In Figs. 9, 10 and 11 the ion charges are plotted on the left, the mol amounts on the right. In the graph for $17 \mathrm{Da}$ (Fig. 9) there appeared a $20 \mu \mathrm{C} / \mathrm{mol}$ signal for the reference substance 


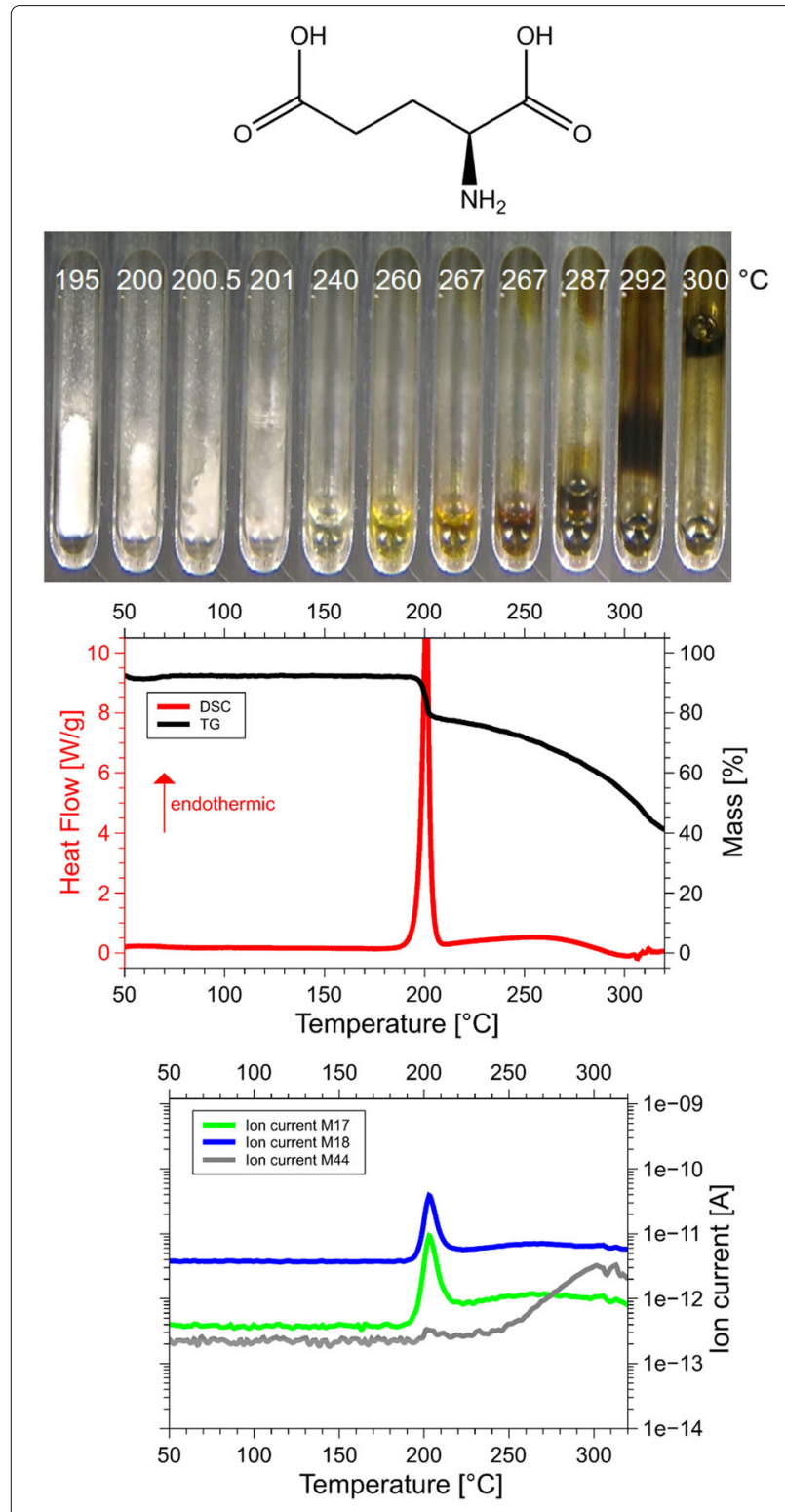

Fig. 5 Glutamate data. $\mathrm{C}_{5} \mathrm{H}_{9} \mathrm{NO}_{4}, 147 \mathrm{Da}, \mathrm{H}_{\mathrm{f}}=-1097 \mathrm{~kJ} / \mathrm{mol}$

X1. Since this definitely cannot contain $\mathrm{NH}_{3}$, a systematic error of $20 \mu \mathrm{C} / \mathrm{mol}$ must be present, though the statistical errors are smaller.

The absolute ion currents of Figs. 9, 10 and 11 are equipment dependent and not significant, but the relative values are encouraging. One $\mathrm{mol} \mathrm{NH}_{3}$ produces $12 \%$ less and $\mathrm{CO}_{2} 54 \%$ more ions than one mol $\mathrm{H}_{2} \mathrm{O}$. Indeed the ionization cross sections of $\mathrm{NH}_{3}, \mathrm{H}_{2} \mathrm{O}$ and $\mathrm{CO}_{2}$ are reported to be in that order [6].

Figures 9, 10, 11 and 12 and Table 1 summarize the experimental data: With the exception of cysteine, thermal decomposition results in three gases, mainly $\mathrm{H}_{2} \mathrm{O}$, less $\mathrm{NH}_{3}$ and hardly any $\mathrm{CO}_{2}$. The weight of these three

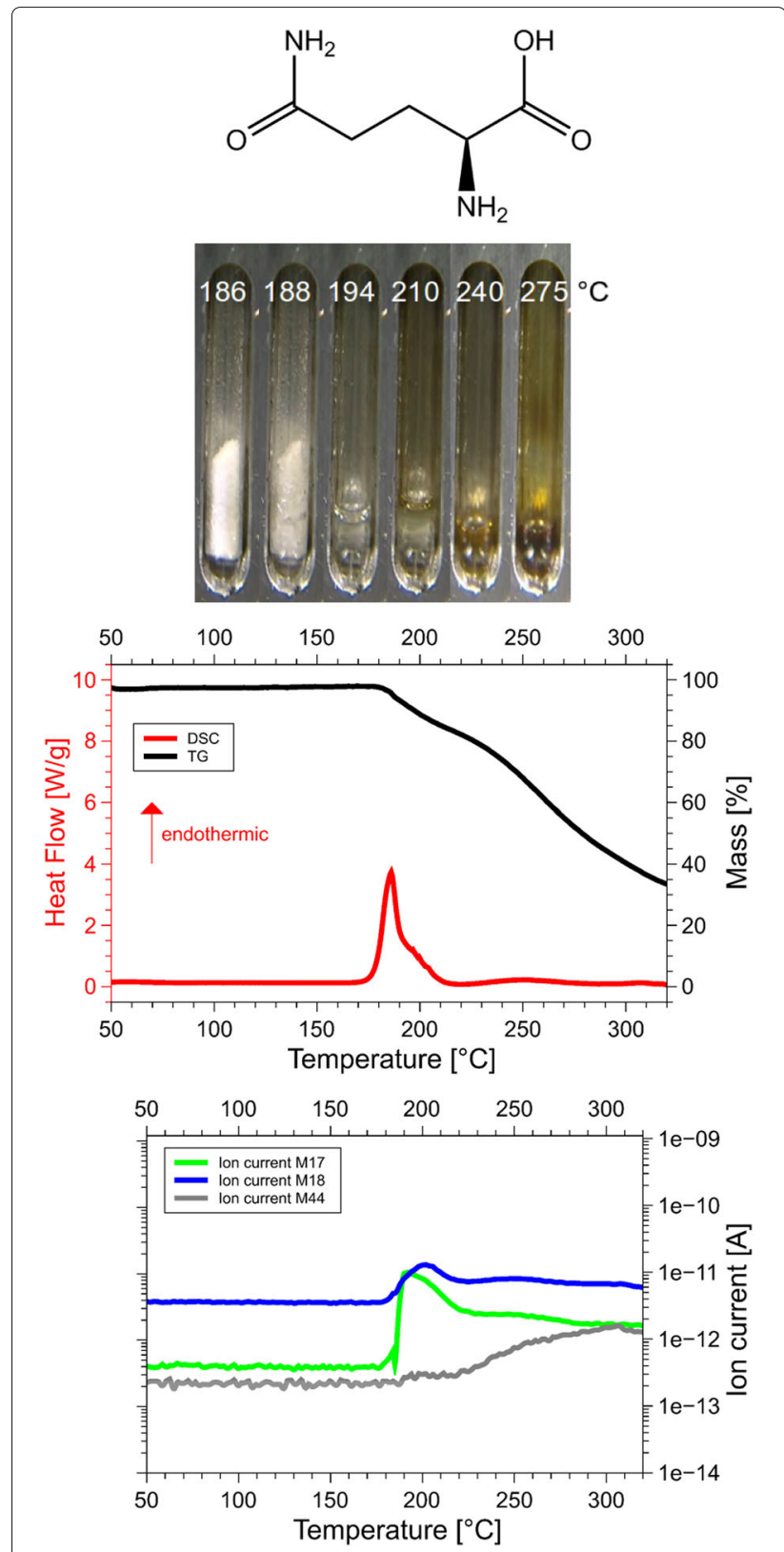

Fig. 6 Glutamine data. $\mathrm{C}_{5} \mathrm{H}_{10} \mathrm{ON}_{2} \mathrm{O}_{3}, 146 \mathrm{Da}, \mathrm{H}_{\mathrm{f}}=-826 \mathrm{~kJ} / \mathrm{mol}$

gases adds up to the weight loss registered by TGA, therefore no other gases evolve in appreciable amount - they are not seen in QMS either. The proximity of the molfractions to integer or half-integer values indicates simple decomposition chains. The process causing the peaks cannot be melting (because of the mass loss), nor sublimation (because of the QMS signals). One concludes that amino acids do not exist in liquid or gaseous form. They decompose endothermally, with heats of decomposition between -72 and $-151 \mathrm{~kJ} / \mathrm{mol}$, at well defined temperatures between $185^{\circ} \mathrm{C}$ and $280^{\circ} \mathrm{C}$. 


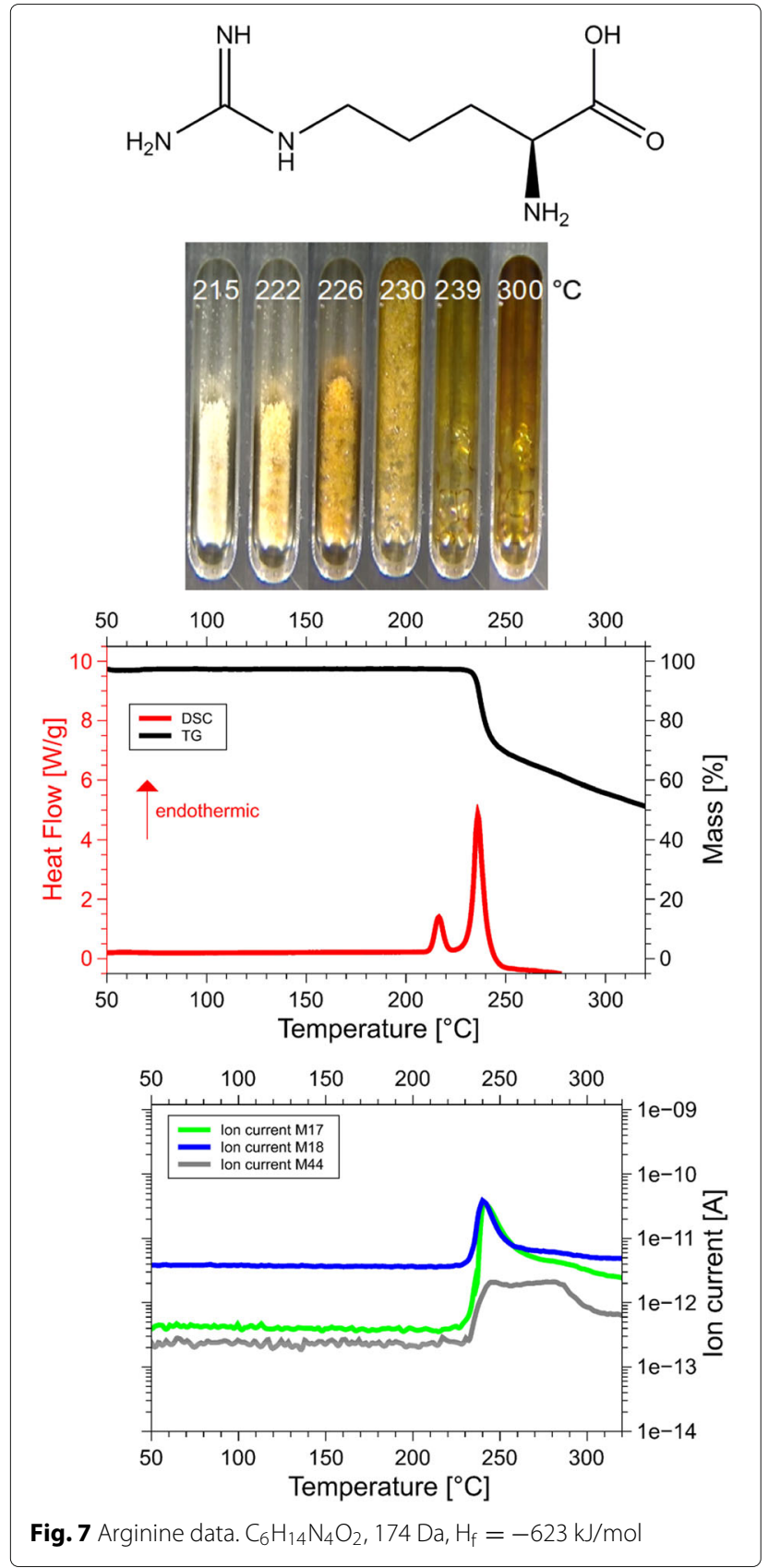

\section{Data analysis, amino acid by amino acid}

These amino acids consist of different side chains attached to the $\mathrm{C} \alpha$ of the same backbone, $\mathrm{NH}_{2}-\mathrm{C} \alpha-\left(\mathrm{C}^{*} \mathrm{OOH}\right)$, but their decomposition chains are quite different. The pyrolytic process is controlled by three balance laws: In terms of $\mathrm{Da}$ the masses must add up, chemically the atomic species must balance, and the enthalpy of formation must equal the enthalpies of formation of the products plus the endothermic heat of reaction. The amounts of volatile products are experimental values (TGA and QMS). For the residues only the mass is experimental,

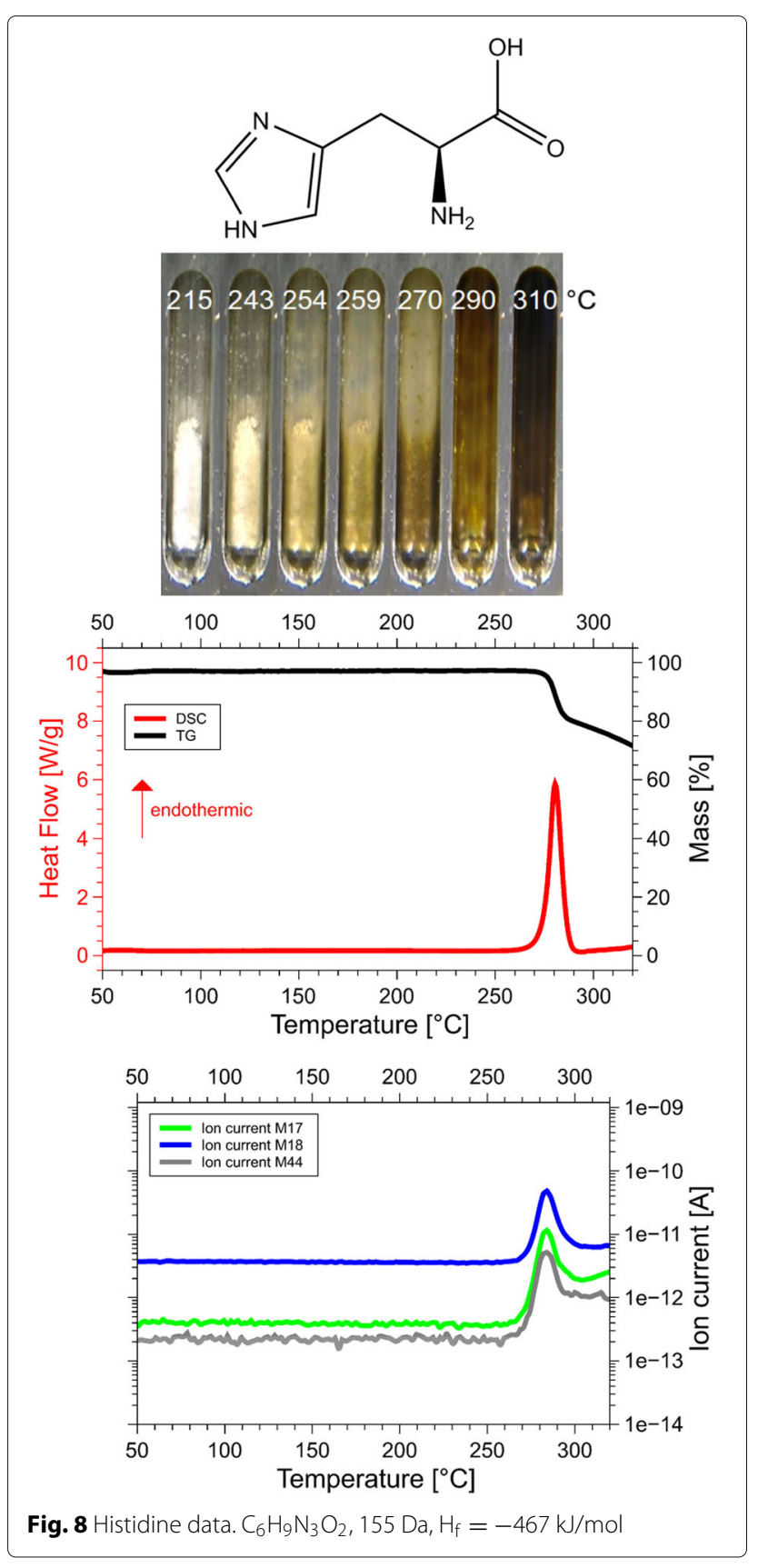

their composition is inferred. In this section we analyze possible pathways. Although the choices, restricted by compositional, mass and enthalpy considerations, are convincing, they cannot be unique beyond doubt. Alternatives to our proposals, but indistinguishable by us, are possible. Analyses of the decomposition chains are, therefore, tentative or speculative. Nevertheless, they are less speculative than those of Rodante et al. [7], who had only TGA and DSC, but no QMS at their disposal. What Acree and Chickos [5] call "sublimation enthalpies" agree more or less with our decomposition 


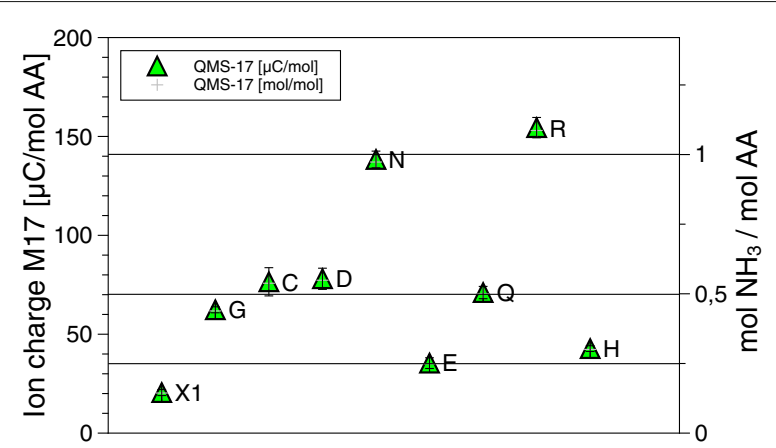

Fig. 9 QMS data for the $17 \mathrm{Da}$ channel. Signals in the $17 \mathrm{Da}$, the $\mathrm{NH}_{3}$ channel, for each of the amino acids. Ionic charges in the peaks on the left, $\mathrm{mol} \mathrm{NH} \mathrm{N}_{3} / \mathrm{mol}$ amino acid on the right. The clustering of $\mathrm{G}, \mathrm{C}$, $\mathrm{D}, \mathrm{Q}$ around $\frac{1}{2} \mathrm{~mol} \mathrm{NH} 3$ per $\mathrm{mol} A \mathrm{~A}$ and of $\mathrm{N}$ and $\mathrm{R}$ around $1 \mathrm{~mol} \mathrm{NH}$ per mol AA is striking

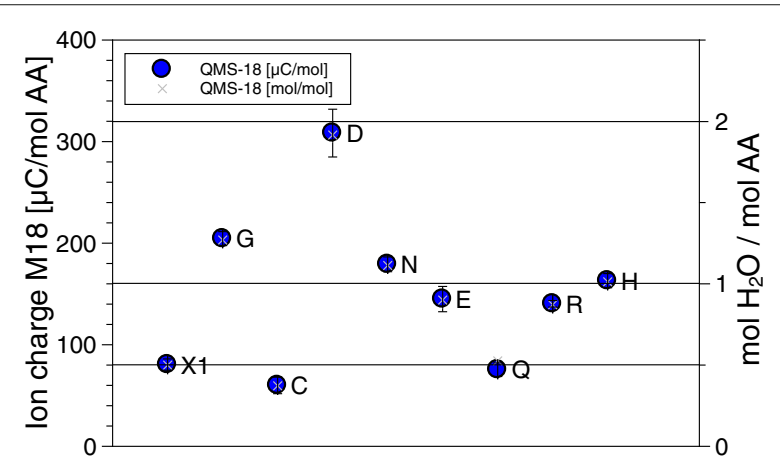

Fig. 10 QMS data for the $18 \mathrm{Da}$ channel. Signals in the $18 \mathrm{Da}$, the $\mathrm{H}_{2} \mathrm{O}$ channel, for each of the amino acids. Ionic charges in the peaks on the left, $\mathrm{mol} \mathrm{H} \mathrm{H}_{2} \mathrm{O} / \mathrm{mol}$ amino acid on the right. The clustering of $\mathrm{C}$ and $\mathrm{Q}$ around the $\frac{1}{2} \mathrm{~mol} \mathrm{H}_{2} \mathrm{O}$ level, of $\mathrm{N}, \mathrm{E}, \mathrm{R}, \mathrm{H}$ around the $1 \mathrm{~mol} \mathrm{H}_{2} \mathrm{O}$ level, and the $2 \mathrm{~mol}$ point for $\mathrm{D}$ are striking enthalpies. One concludes that they must refer to decomposition, not merely sublimation without composition change.

We made use of the enthalpy values listed for standard conditions [8] without minor corrections for specific heats and entropies up to the actual reaction temperatures. Moreover, hydrogen gas escapes our attention, it is too light (2 Da) to be registered in QMS and TGA, nor does it appear in the enthalpy sum, its heat of formation being zero by definition. With exception of hydrogen, the mass balance, controlled by TGA, confirms that beyond the residue and the three gases, nothing else is formed. The real constraint is the enthalpy balance. For the enthalpy balance production of water is necessary. The expression of the formation enthalpies of the 20 amino acids $\left(\mathrm{C}_{a} \mathrm{H}_{b} \mathrm{~N}_{c} \mathrm{O}_{d} \mathrm{~S}_{e}\right)$ has the least square fit $\mathrm{H}_{\mathrm{f}}\left(\mathrm{C}_{a} \mathrm{H}_{b} \mathrm{~N}_{c} \mathrm{O}_{d} \mathrm{~S}_{e}\right)$ $=30.3 a-37.8 b+16.5 c-182.4 d-71.3 e[\mathrm{~kJ} / \mathrm{mol}]$. The oxygens counterbalance the others with $-182 \mathrm{~kJ} / \mathrm{mol}$. The obvious way of efficiently transferring enthalpy from the reactants to the products is the formation of water, with $\mathrm{H}_{\mathrm{f}}\left(\mathrm{H}_{2} \mathrm{O}\right)=-242 \mathrm{~kJ} / \mathrm{mol}$.

Detailed analysis for each amino acid is helped by preliminary reference to a few reactions possible in principle. $\mathrm{CO}_{2}$ production in Cys is obviously a special case. In principle one expects the $\mathrm{N}$-termini to be stable, making desamination to produce $\mathrm{NH}_{3}$ unlikely. Nitrogen in the side chains is another matter, indeed the $\mathrm{NH}_{3}$ producing Asn and Arg have nitrogen in their side chains. The predominance of $\mathrm{H}_{2} \mathrm{O}$ production indicates instability of the $\mathrm{C}$-terminus beyond the $\mathrm{C}^{*}$ atom, where dehydration can occur by $n$-oligomerization, which yields $(n-1) / n$ mol $\mathrm{H}_{2} \mathrm{O} / \mathrm{mol} \mathrm{AS}$, from dimerization for $n=2$, to $1 \mathrm{~mol}$ $\mathrm{H}_{2} \mathrm{O} /$ mol for $\mathrm{n} \rightarrow \infty$ in polymerization. A special case of dimerization is external cyclization in the diketopiperazine reaction, which yields $1 \mathrm{~mol} \mathrm{H}_{2} \mathrm{O} / \mathrm{mol} \mathrm{AA}$. These

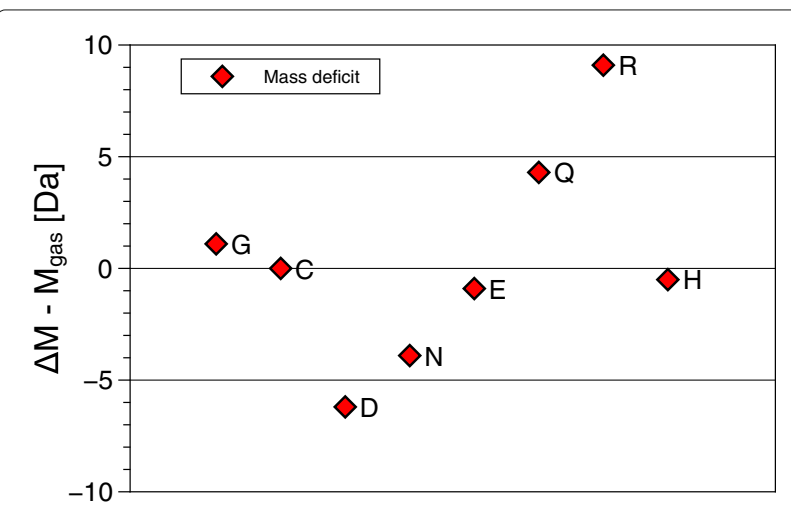

Fig. 12 Comparison of mass balances registered by TGA and QMS experiments. The difference between the mass loss registered by TGA, $\Delta \mathrm{M}$ and the volatile mass found as $\mathrm{NH}_{3}, \mathrm{H}_{2} \mathrm{O}, \mathrm{CO}_{2}$ and $\mathrm{H}_{2} \mathrm{~S}, \Delta \mathrm{M}$ - $M_{\text {gas }}$ remains below $|9| \mathrm{Da}$. This is confirmation that no other gases are produced 
Table 1 Data overview

\begin{tabular}{|c|c|c|c|c|c|c|c|c|c|c|c|c|}
\hline AAA & A & $\begin{array}{l}\text { M.W. } \\
\text { Da }\end{array}$ & $\begin{array}{l}\mathrm{H}_{\mathrm{f}} \\
\mathrm{kJ} / \mathrm{mol}\end{array}$ & $\begin{array}{l}\mathrm{T}_{\text {peak }} \\
{ }^{\circ} \mathrm{C} \\
\end{array}$ & $\begin{array}{l}\mathrm{H}_{\text {peak }} \\
\mathrm{kJ} / \mathrm{mol}\end{array}$ & $\begin{array}{l}\Delta \mathrm{M} \\
\mathrm{Da}\end{array}$ & $\begin{array}{l}\text { QMS-17 } \\
\mathrm{mol} / \mathrm{mol}\end{array}$ & $\begin{array}{l}\text { QMS-18 } \\
\text { mol/mol }\end{array}$ & $\begin{array}{l}\text { QMS-44 } \\
\mathrm{mol} / \mathrm{mol}\end{array}$ & $\begin{array}{l}\text { Mgas } \\
\text { Da }\end{array}$ & $\begin{array}{l}\Delta \mathrm{M}-\mathrm{M}_{\text {gas }} \\
\mathrm{Da}\end{array}$ & $\begin{array}{l}\mathrm{H}_{\text {res }} \\
\mathrm{kJ} / \mathrm{mol}\end{array}$ \\
\hline Gly & G & 75 & -529 & 250 & 64 & 35 & $0,44 \pm 0,01$ & $1,27 \pm 0,04$ & $0,07 \pm 0,00$ & 34 & 1 & -172 \\
\hline Cys & C & 121 & -534 & 245 & 94 & 98 & $0,54 \pm 0,05$ & $0,37 \pm 0,05$ & $0,99 \pm 0,07$ & 59 & 39 & -27 \\
\hline Asp & D & 133 & -973 & 256 & 121 & 39 & $0,55 \pm 0,04$ & $1,92 \pm 0,15$ & $0,03 \pm 0,00$ & 45 & -6 & -473 \\
\hline Asn & $N$ & 132 & -789 & 225 & 118 & 35 & $0,97 \pm 0,03$ & $1,11 \pm 0,05$ & $0,06 \pm 0,00$ & 39 & -4 & -451 \\
\hline Glu & $E$ & 147 & -1010 & 201 & 89 & 20 & $0,25 \pm 0,02$ & $0,90 \pm 0,08$ & $0,00 \pm 0,00$ & 21 & -1 & -779 \\
\hline Gln & Q & 146 & -826 & 185 & 77 & 22 & $0,50 \pm 0,02$ & $0,53 \pm 0,12$ & $0,00 \pm 0,00$ & 18 & 4 & -675 \\
\hline Arg & $\mathrm{R}$ & 174 & -624 & 236 & 54 & 47 & $1,09 \pm 0,04$ & $0,87 \pm 0,02$ & $0,07 \pm 0,01$ & 37 & 9 & -334 \\
\hline $\mathrm{His}$ & $\mathrm{H}$ & 155 & -467 & 280 & 82 & 27 & $0,30 \pm 0,01$ & $1,01 \pm 0,04$ & $0,10 \pm 0,00$ & 28 & -1 & -169 \\
\hline
\end{tabular}

The three letter codes, and one letter codes, of the amino acids are listed in the first two columns. Their molecular weight is given in units of Dalton [Da] in the third column, the literature values [8] of their heat of formation, $\mathrm{H}_{\mathrm{f}}$ in $[\mathrm{kJ} / \mathrm{mol}]$ in the fourth. Columns five and six refer to our experimental calorimetric data: the temperature where the maxima of the peaks occur, $T_{\text {peak, }}$ in centigrades, and the areas of the endothermic peaks, $\mathrm{H}_{\text {peak }}$ in $[\mathrm{kJ} / \mathrm{mol}]$. The mass spectrometric data follow in columns seven to ten: $\Delta \mathrm{M}$ in Dalton [Da] is the total weight loss in each peak, measured by TGA. QMS-17, given in units [mol/mol], is the mass found in the channel with molecular weight $17 \mathrm{Da}$, in all likelihood $\mathrm{NH}_{3}$. The unit is amount of mols in channel 17-Da per mol amino acid. The column QMS-18 lists the same parameter for the channel with molecular weight 18 Da, in all likelihood $\mathrm{H}_{2} \mathrm{O}$. The column QMS-44 the same for the channel with molecular weight $44 \mathrm{Da}$, in all likelihood $\mathrm{CO}_{2}$. For example, the value 0.44 in the first line means that $0.44 \mathrm{~mol} \mathrm{NH} 3$ per mol Gly passed through the mass spectrometer. The next column, titled $\mathrm{M}_{\text {gass, }}$ is the calculated sum of the molecular weights found in the $17 \mathrm{Da}$, plus 18 $\mathrm{Da}$, plus $44 \mathrm{Da}$ channels, i.e. in the first line $34 \mathrm{Da}=0.44 \times 17+1.27 \times 18+0.07 \times 44$ [Da]. Generally, if there are $\mathrm{a}, \mathrm{b}$ and $\mathrm{c}$ mols of $\mathrm{NH}_{3}, \mathrm{H}_{2} \mathrm{O}$ and $\mathrm{CO}_{2}$, respectively, $\mathrm{M}_{\text {gas }}$ $=17 \mathrm{a}+18 \mathrm{~b}+44 \mathrm{c}$. The penultimate column, $\Delta \mathrm{M}-\mathrm{M}_{\mathrm{gas}}$, lists the difference of weight loss, $\Delta \mathrm{M}$ measured by DTA and the total mass $\mathrm{M}_{\mathrm{gas}}$, found as $\mathrm{NH}_{3}, \mathrm{H}_{2} \mathrm{O}$ and $\mathrm{CO}_{2}$. The smallness of $\Delta \mathrm{M}-\mathrm{M}_{\text {gas }}$ assures that, within error limits, volatile products were only $\mathrm{NH}_{3}, \mathrm{H}_{2} \mathrm{O}$ and $\mathrm{CO}_{2}$. The notable exception is Cystein, which gives off another gas, see "Cysteine" subsections in "Raw data" and "Data analysis" sections of the text. The last column is the enthalpy of formation of the solid residue, which is the heat of formation $\mathrm{H}_{f}(\mathrm{~s})$ of the solid amino acid [8] minus the heats of formation used to form $\mathrm{NH}_{3}, \mathrm{H}_{2} \mathrm{O}$ and $\mathrm{CO}_{2}$. It is calculated as $\mathrm{H}_{\mathrm{res}}=\mathrm{H}_{\mathrm{f}}-45 \mathrm{a}-242 \mathrm{~b}-396 \mathrm{c}$

involve joining $\mathrm{N}$ - and $\mathrm{C}$ - termini in a dehydration reaction. For long side chains also internal cyclization, where the end of the side chain connects to the C-terminus can be envisaged. Integer and half-integer mol values restrict the choice for the residues, but not unequivocally.

All DSC peaks are endothermic, their areas are given negative signs. With this convention endothermic evaporation and exothermic production of water are written as

$$
\begin{array}{rlrl}
\mathrm{H}_{2} \mathrm{O}(\mathrm{l}) & \longrightarrow & \mathrm{H}_{2} \mathrm{O}(\mathrm{g}) \\
-\mathbf{2 8 5 . 5} & & -\mathbf{2 4 1 . 8} \quad-\mathbf{4 4} \mathbf{k J} / \mathbf{m o l} \\
& \\
2\left(\mathrm{H}_{2}\right)+\mathrm{O}_{2} & \longrightarrow 2\left(\mathrm{H}_{2} \mathrm{O}\right)(\mathrm{g}) \\
\mathbf{0} & \mathbf{0} & 2(-\mathbf{2 4 1 . 8})+2(\mathbf{2 4 1 . 8}) \mathrm{kJ} / \mathbf{m o l}
\end{array}
$$

\section{Glycine}

Glycine, Gly, G, $\mathrm{C}_{2} \mathrm{H}_{5} \mathrm{NO}_{2}, 75 \mathrm{Da}, \mathrm{H}_{\mathrm{f}}=-528 \mathrm{~kJ} / \mathrm{mol}$. Simple endothermic peak at $250{ }^{\circ} \mathrm{C}, \mathrm{H}_{\text {peak }}=-72.1 \mathrm{~kJ} / \mathrm{mol}$.

The QMS signal of $\frac{3}{2} \mathrm{~mol} \mathrm{H}_{2} \mathrm{O} / \mathrm{mol}$ Gly plus $\frac{1}{2} \mathrm{~mol}$ $\mathrm{NH}_{3} / \mathrm{mol}$ Gly is beyond doubt, it is confirmed by the mass loss of $35 \mathrm{Da} / \mathrm{mol}$ Gly. This leaves only $10 \%$ of the original hydrogen for the residue. The triple and double bonds in carbon rich $\mathrm{C}_{4} \mathrm{HNO}, \mathrm{C}_{3} \mathrm{HNO}$ and $\mathrm{C}_{2} \mathrm{HNO}$ preclude them enthalpy wise and make deposition of carbon likely, leaving $-280 \mathrm{~kJ} / \mathrm{mol}=\mathrm{x}$ for the moiety $\mathrm{CHNO}$, which is the composition of the peptide bond. The database ChemSpider [9] lists two symmetric molecules consisting entirely of peptide bonds, 1,3-Diazetine2,4-dione, $\quad \mathrm{C}_{2} \mathrm{H}_{2} \mathrm{~N}_{2} \mathrm{O}_{2}$, chemspider 11593418, 86 $\mathrm{Da}$, (Fig. 13a) or its isomer 1,2-Diazetine-3,4-dione, $\mathrm{C}_{2} \mathrm{H}_{2} \mathrm{~N}_{2} \mathrm{O}_{2}$, chemspider 11383421, 86 Da, Fig. 13b. The scarcity of hydrogen is such that not even the smallest lactam, 2-Aziridinone, $\mathrm{C}_{2} \mathrm{H}_{3} \mathrm{NO}, 57 \mathrm{Da}$, chemspider 10574050 , bp $57{ }^{\circ} \mathrm{C}$ (Fig. 13c) can serve as residue.

The simplest pathway seems the formation of linear Glycylglycine, chemspider 10690 (Fig. 13d), m.p. $255{ }^{\circ} \mathrm{C}$ (which is $\mathrm{T}_{\text {peak! }}$ ) $\mathrm{C}_{4} \mathrm{H}_{8} \mathrm{~N}_{2} \mathrm{O}_{3}, \mathrm{H}_{\mathrm{f}}(\mathrm{s})=-748 \mathrm{~kJ} / \mathrm{mol}$ [8] from which the central peptide bond $-(\mathrm{C}=\mathrm{O})-\mathrm{NH}-$ is detached by cutting off the $\mathrm{NH}_{2}-\mathrm{C} \alpha-\mathrm{H}_{2}-$ group on one, and the $\mathrm{C} \alpha-\mathrm{H}_{2}-\mathrm{C}^{*} \mathrm{OOH}$ group on the other side. The former makes $\mathrm{NH}_{3}$ plus $\mathrm{C}$, the latter makes $2 \mathrm{C}$ plus $2 \mathrm{H}_{2} \mathrm{O}$. This process is specific for the glycine dimer, in which the $\mathrm{C}^{\alpha}$ atoms are not protected by proper sidechains, they are just $-\mathrm{C} \alpha-\mathrm{H}_{2}-$ units. This pathway to shear peptide bonds is of interest in the context of possible peptide nucleic acid (PNA) synthesis [10] via $\mathrm{N}$-2-aminoethylglycine (AEG), $\mathrm{C}_{4} \mathrm{H}_{10} \mathrm{~N}_{2} \mathrm{O}_{2}$, chemspider 379422, which is deoxidized diglycine, 2 Gly $\longrightarrow \mathrm{O}_{2}+$ AEG.

$$
\begin{aligned}
& 4\left(\mathrm{C}_{2} \mathrm{H}_{5} \mathrm{NO}_{2}\right) \longrightarrow 6\left(\mathrm{H}_{2} \mathrm{O}\right)+2\left(\mathrm{NH}_{3}\right)+6 \mathrm{C}+2(\mathrm{CHNO}) \\
& \begin{array}{lllllll}
-2112 & -1452 & -92 & 0 & 2 & \times & -288 \mathrm{~kJ} / \mathrm{mol} \text {, }
\end{array}
\end{aligned}
$$




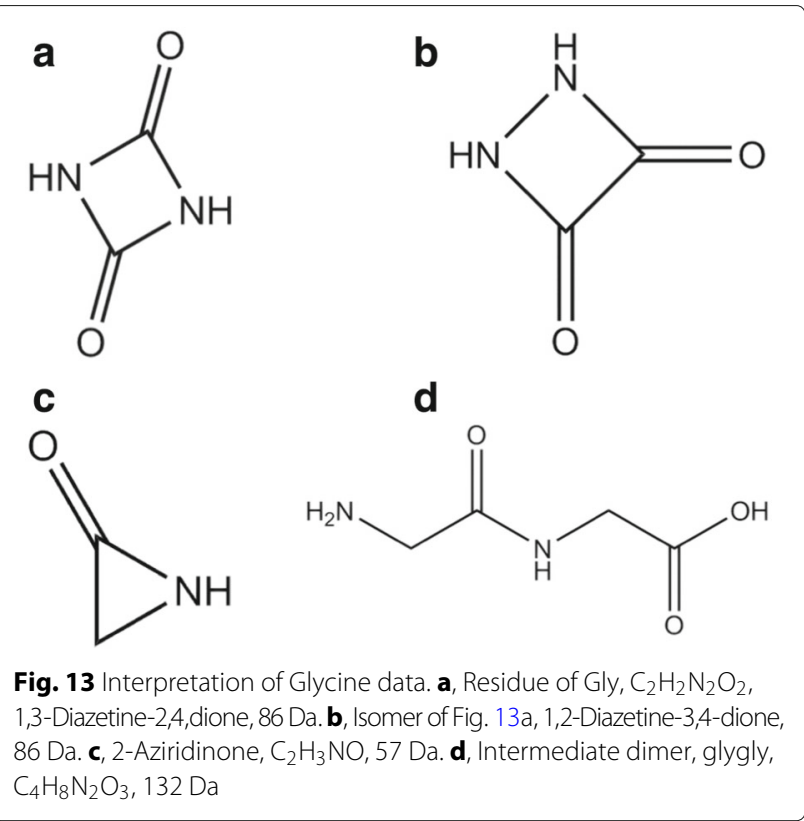

\section{Cysteine}

Cysteine, Cys, C, $\mathrm{C}_{3} \mathrm{H}_{7} \mathrm{NO}_{2} \mathrm{~S}: 121 \mathrm{Da}, \mathrm{H}_{\mathrm{f}}=-534 \mathrm{~kJ} / \mathrm{mol}$.

$\mathrm{T}_{\text {peak }}=221{ }^{\circ} \mathrm{C}$ with a mass loss of $98 \mathrm{Da}, \mathrm{H}_{\text {peak }}=$ $-96 \mathrm{~kJ} / \mathrm{mol}$.

The clear $1 \mathrm{~mol} \mathrm{CO}_{2}$ signal leaves no oxygen to form $\mathrm{H}_{2} \mathrm{O}$, therefore the spurious $18 \mathrm{Da}$ line must stem from a systematic error. There is also $\frac{1}{2} \mathrm{~mol} \mathrm{NH}_{3} / \mathrm{mol}$ Cys. For $\mathrm{H}_{2} \mathrm{~S}$ there is indeed a signal at $34 \mathrm{Da}$. It corresponds to $1 \mathrm{~mol}$, because the ionization cross sections of $\mathrm{H}_{2} \mathrm{~S}$ and $\mathrm{H}_{2} \mathrm{O}$ are nearly identical, so that the calibration of Fig. 10 applies. The mass loss of $44+34+8.5=70 \%$ of $121 \mathrm{Da}$ agrees with TGA. Chemical analysis found no sulfur in the residue. No possibility for forming disulfide bridges between molecules is left. Neither COS nor $\mathrm{CS}_{2}$ was found. The total reaction is

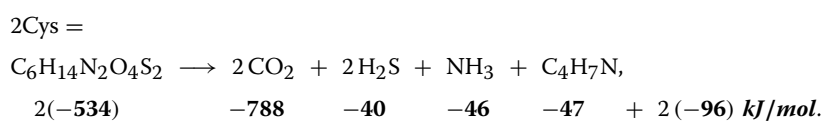

On the left $-1068 \mathrm{~kJ}$, on the right $-1113 \mathrm{~kJ}$. Pathway to the formation of $\mathrm{C}_{4} \mathrm{H}_{7} \mathrm{~N}$ might be ejection of the carboxyl group $-\mathrm{C}^{*} \mathrm{OOH}$ and the $-\mathrm{SH}$ group from Cys, the remaining chain $\mathrm{NH}_{2}-\mathrm{C} \alpha-\mathrm{C}^{*}$ is too short for internal, but suitable for external cyclization. Two of these form the asymmetric 5-ring (3-pyrrolidinamine, chemspider 144134), Fig. 14a, from which the $-\mathrm{NH}_{2}$ is cutt off. Indeed the $\frac{1}{2} \mathrm{NH}_{3}$ ejected confirms such dimerization. That leaves the molecule $\mathrm{C}_{4} \mathrm{H}_{7} \mathrm{~N}$ : 2,5-Dihydro- $1 \mathrm{H}-$ pyrrole, chemspider 13870958 , b.p. $90{ }^{\circ} \mathrm{C}, 69 \mathrm{Da}, \mathrm{H}_{\mathrm{f}}(\mathrm{s})=$ $-46.6 \mathrm{~kJ} / \mathrm{mol}$ (Fig. 14b), or another pyrroline, with the double bond elsewhere in the ring. Indeed there is heavy

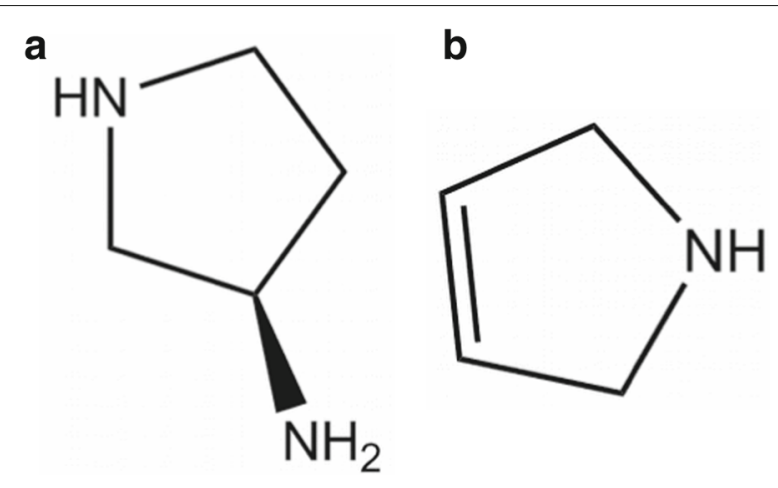

Fig. 14 Interpretation of Cysteine data. a, Intermediate compound: 3-pyrrolidinamine, chemspider 144134, 86 Da. b. Residue of Cys, $\mathrm{C}_{4} \mathrm{H}_{7} \mathrm{~N}, 2,5$-Dihydro-1H-pyrrole, chemspider 13870958, $69 \mathrm{Da}$

boiling beyond the peak. In view of the richness in hydrogen, several small hydrocarbon lines are not surprising.

\section{Aspartic acid}

Aspartic acid, Asp, D, $\mathrm{C}_{4} \mathrm{H}_{7} \mathrm{NO}_{4}: 133 \mathrm{Da}, \mathrm{H}_{\mathrm{f}}=-973 \mathrm{~kJ} / \mathrm{mol}$. DSC shows two distinct peaks, at $230{ }^{\circ} \mathrm{C}$ and at $250{ }^{\circ} \mathrm{C}$, in each of which $1 \mathrm{~mol} \mathrm{H}_{2} \mathrm{O} / \mathrm{mol} \mathrm{Asp}$ is ejected. The endothermic heats are -64 and $-61 \mathrm{~kJ} / \mathrm{mol}$, respectively. The substance stays a powder up to $294{ }^{\circ} \mathrm{C}$, i.e. solid/solid transformation in the peak. The reaction

$$
\begin{array}{lllll}
\mathrm{C}_{4} \mathrm{H}_{7} \mathrm{NO}_{4} \longrightarrow & \mathrm{H}_{2} \mathrm{O} & +\mathrm{H}_{2} \mathrm{O} & +\mathrm{C}_{4} \mathrm{H}_{3} \mathrm{NO}_{2} \\
-\mathbf{9 7 3} & \mathbf{2 4 2} & -\mathbf{2 4 2} & y & (-\mathbf{1 2 5}) \mathrm{kJ} / \mathbf{m o l} \text {, }
\end{array}
$$

with calculated $y=-364 \mathrm{~kJ} / \mathrm{mol}$, which is reasonable for the formation enthalpy of the polysuccinimide unit (PSI). The molecular weight of $\mathrm{C}_{4} \mathrm{H}_{3} \mathrm{NO}_{2}$ is $97 \mathrm{Da}$.

The compound $\left(\mathrm{C}_{4} \mathrm{H}_{3} \mathrm{NO}_{2}\right)_{n}$ is polysuccinimide. The two peaks prove that the reaction occurs in two steps, in the first at $230{ }^{\circ} \mathrm{C}$ the condensation reaction produces polyaspartic acid, $\mathrm{n}$ Asp $\longrightarrow \mathrm{H}_{2} \mathrm{O}+(A s p)_{n}$, in the second at $250{ }^{\circ} \mathrm{C}$ the poly-Asp degrades to polysuccinimide (PSI) by ejection of another $1 \mathrm{~mol} \mathrm{H}_{2} \mathrm{O} / \mathrm{mol}$ Asp. Such a reaction was reported by Schiff [11]. The molecule drawn in Fig. 15 is $\beta$-poly-Asp, there is an isomer, $\alpha$-poly-Asp, where the next $C$ in the ring forms a bond to its neighbour. We have no possibility to decide between the two.

\section{Asparagine}

Asparagine, Asn, N, $\mathrm{C}_{4} \mathrm{H}_{8} \mathrm{~N}_{2} \mathrm{O}_{3}: 132 \mathrm{Da}, \mathrm{H}_{\mathrm{f}}=-789 \mathrm{~kJ} / \mathrm{mol}$.

In the broad peak at $232{ }^{\circ} \mathrm{C}, 1 \mathrm{~mol} \mathrm{H}_{2} \mathrm{O} / \mathrm{mol} \mathrm{Asn}$ and 1 $\mathrm{mol} \mathrm{NH} 3 / \mathrm{mol}$ Asn are ejected. $\mathrm{H}_{\text {peak }}=-122 \mathrm{~kJ} / \mathrm{mol}$. The product stays a white powder up to $265{ }^{\circ} \mathrm{C}$, i.e. there is a solid/solid transformation in the reaction

$$
\begin{aligned}
& \mathrm{C}_{4} \mathrm{H}_{8} \mathrm{~N}_{2} \mathrm{O}_{3} \longrightarrow \mathrm{H}_{2} \mathrm{O}+\mathrm{NH}_{3}+\mathrm{C}_{4} \mathrm{H}_{3} \mathrm{NO}_{2}
\end{aligned}
$$

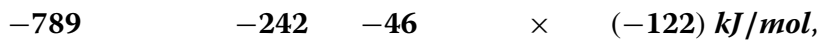

with calculated $x=-379 \mathrm{~kJ} / \mathrm{mol}$. In the Asp decomposition, $\mathrm{H}_{\mathrm{f}}\left(\mathrm{C}_{4} \mathrm{H}_{3} \mathrm{NO}_{2}\right)$ was calculated as $y=-364 \mathrm{~kJ} / \mathrm{mol}$. 


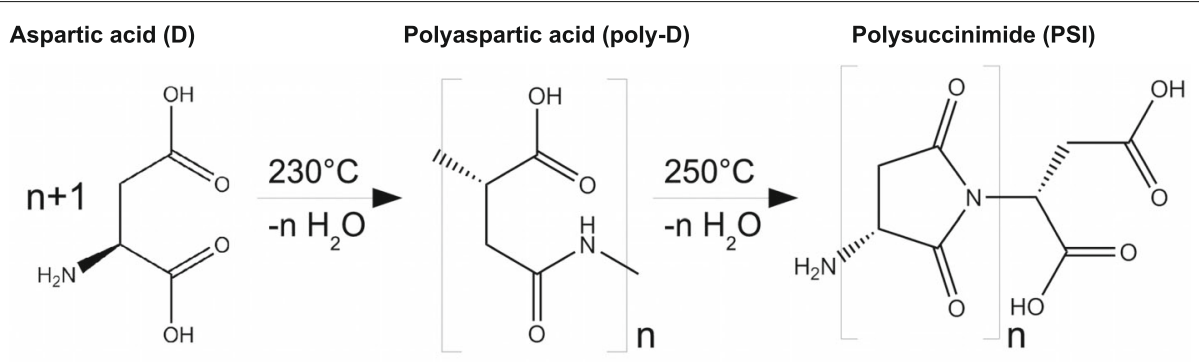

Fig. 15 Interpretation of Aspartate data. The pathway from Aspartic acid (D) to polysuccimide (PSI). Compared with succinimide, the N-C bond in polysuccinimide economizes two hydrogen atoms

The two values agree, although because of their histories, the two PSI are not identical. If Asn followed the example of Asp, it would eject $1 \mathrm{~mol} \mathrm{H}_{2} \mathrm{O} / \mathrm{mol}$ Asn in the condensation reaction $n$ Asn $\longrightarrow \mathrm{H}_{2} \mathrm{O}+$ $(A s n)_{n}$, poly- $\mathrm{N}$, followed by degradation of poly-N to polysuccinimide (PSI) by ejection of $1 \mathrm{~mol} \mathrm{NH}_{3} / \mathrm{mol}$ Asn. If, however, the $\mathrm{H}_{2} \mathrm{O}$ of the condensation reaction is not ejected but retained, it can replace the $-\mathrm{NH}_{2}$ in poly- $\mathrm{N}$ by $-\mathrm{OH}$. According to Asn $->\mathrm{NH}_{3}+$ poly$\mathrm{D}$, this amounts to the formation of polyaspartic acid from asparagine by ejection of $\mathrm{NH}_{3}$. The poly- $\mathrm{D}$ then degrades to polysuccinimide (PSI) by ejection of $1 \mathrm{~mol}$ $\mathrm{H}_{2} \mathrm{O} / \mathrm{mol}$ Asn. Apparently both alternatives shown in Fig. 16 occur, and there is one broad peak containing both $\mathrm{NH}_{3}$ and $\mathrm{H}_{2} \mathrm{O}$.

Though the formulae for PSI formed from Asp and from Asn, are the same, $\left(\mathrm{C}_{4} \mathrm{H}_{3} \mathrm{NO}_{2}\right)_{n}$, these two residues need not be identical. For kinetic reasons the oligomerization or polymerization might have proceeded to different lengths in poly-Asp and poly-Asn, therefore the degraded products PSI might have different lengths, with different stabilities and melting points. Moreover, the telomers are different, $-\mathrm{OH}$ for PSI from Asp and $-\mathrm{NH}_{2}$ for PSI from Asn. Indeed PSI from Asp remains a white powder up to $289{ }^{\circ} \mathrm{C}$, while PSI from Asn starts melting at $289^{\circ} \mathrm{C}$.

\section{Glutamic acid}

Glutamic acid, Glu, E, $\mathrm{C}_{5} \mathrm{H}_{9} \mathrm{NO}_{4}$ :

$147 \mathrm{Da}, \mathrm{H}_{\mathrm{f}}=-1097 \mathrm{~kJ} / \mathrm{mol} ; \mathrm{T}_{\text {peak }}=200^{\circ} \mathrm{C}, \mathrm{H}_{\text {peak }}=$ $-88 \mathrm{~kJ} / \mathrm{mol}$.

At $200{ }^{\circ} \mathrm{C}, 1 \mathrm{~mol} \mathrm{H}_{2} \mathrm{O} / \mathrm{mol} \mathrm{Glu}$ is seen in QMS, the DSC area is $-121 \mathrm{~kJ} / \mathrm{mol}$, mass loss in the peak is $12 \%$ (17 Da). The dehydration of Glu has been known for a long time [12].

$$
\begin{array}{llc}
\mathrm{C} 5 \mathrm{H} 9 \mathrm{NO} 4 & \mathrm{H} 2 \mathrm{O} \\
-\mathbf{1 0 9 7} & \mathbf{- 2 4 2} & \mathrm{C} 5 \mathrm{H} 7 \mathrm{NO} 3(\mathrm{l}) \\
& & (-\mathbf{1 2 1}) \mathbf{k J} / \mathbf{m o l},
\end{array}
$$

with calculated $x=-734 \mathrm{~kJ} / \mathrm{mol}$ for $\mathrm{H}_{\mathrm{f}}\left(\mathrm{C}_{5} \mathrm{H}_{7} \mathrm{NO}_{3}\right)$, pyroglutamic acid, chemspider $485,129 \mathrm{Da}, \mathrm{T}_{\mathrm{m}}=184{ }^{\circ} \mathrm{C}$, b.p. $=433^{\circ} \mathrm{C}$ (Fig. 17a). This lactam is biologically important,

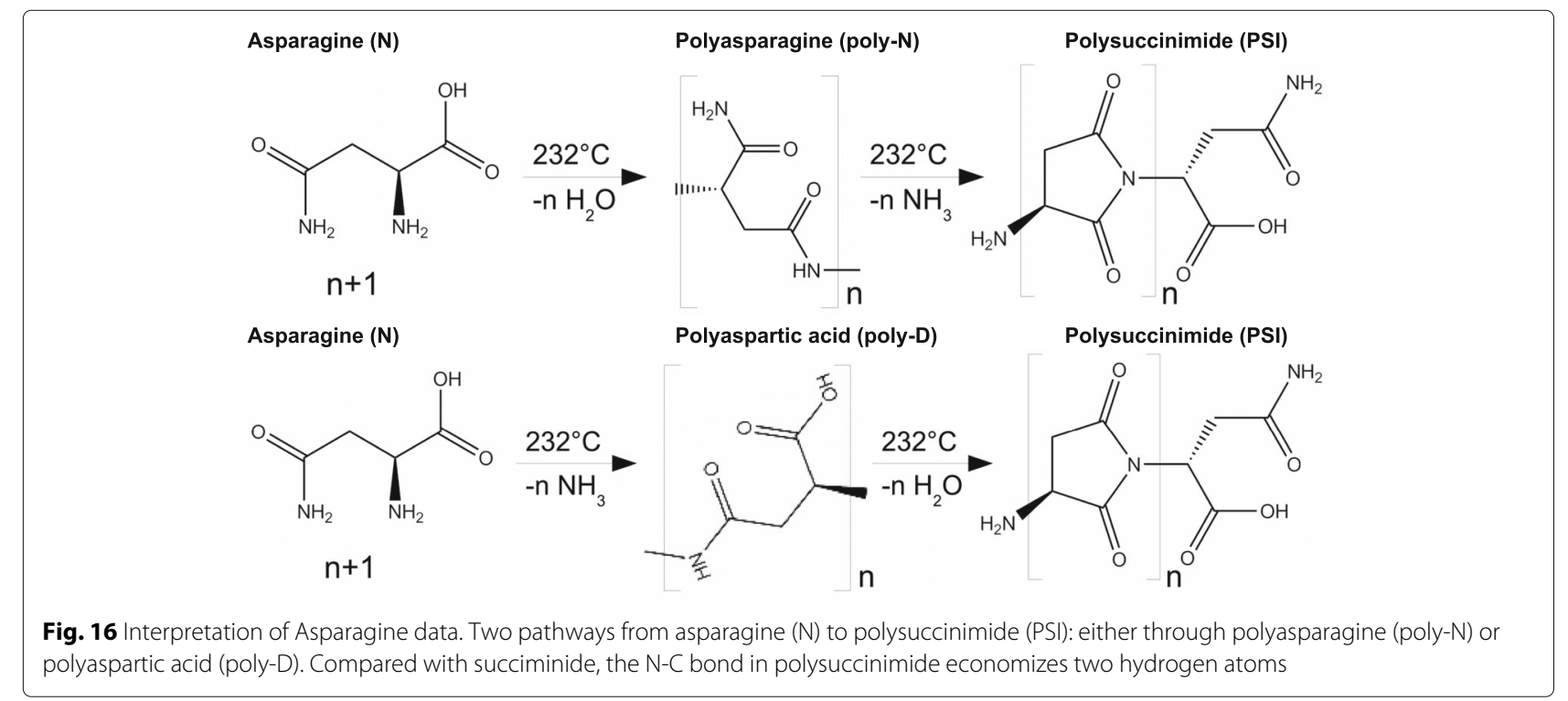


but its enthalpy of formation is apparently not known. Known is the $\mathrm{H}_{\mathrm{f}}(\mathrm{s})=-459 \mathrm{~kJ} / \mathrm{mol}$ and $\mathrm{H}_{\mathrm{f}}(\mathrm{g})=-375 \mathrm{~kJ} / \mathrm{mol}$ for $\mathrm{C}_{4} \mathrm{H}_{5} \mathrm{NO}_{2}$, succinimide, $99 \mathrm{Da}$, the five ring with $\mathrm{O}=$ and $=\mathrm{O}$ as wings (the structure is like pyroglutamic acid, but with the carboxyl group $-\mathrm{COOH}$ replaced by $=\mathrm{O}$, shown in Fig. 17b). The additional $\mathrm{O}$ should add about $-200 \mathrm{~kJ} / \mathrm{mol}$, which makes the $-734 \mathrm{~kJ} / \mathrm{mol}$ for pyroglutamic acid plausible. The TGA weight loss beyond the peak is evaporation. Pyroglutamic acid is formed by inner cyclization of $\mathrm{E}$ : after the $-\mathrm{OH}$ hanging on $\mathrm{C}^{\delta}$ is ejected, the $\mathrm{C}^{\delta}$ joins the $-\mathrm{NH}_{2}$ hanging on $\mathrm{C}^{\alpha}$. This was suggested by Mosqueira et al. [13], ours is the first experimental evidence for this process. Since QMS does not show any $\mathrm{CO}_{2}$, the reaction to $\mathrm{C}_{4} \mathrm{H}_{7} \mathrm{NO}$, the lactam pyrrolidone (Fig. 17c), $85 \mathrm{Da}, \mathrm{T}_{\mathrm{m}}=25{ }^{\circ} \mathrm{C}$, b.p. $=245^{\circ} \mathrm{C}, \mathrm{H}_{\mathrm{f}}(\mathrm{l})=$ $-286 \mathrm{~kJ} / \mathrm{mol}$, yellow liquid, can be ruled out, although cutting off the $\mathrm{CO}_{2}$ is sterically tempting.

\section{Glutamine}

Glutamine, Gln, Q, $\mathrm{C}_{5} \mathrm{H}_{10} \mathrm{~N}_{2} \mathrm{O}_{3}: 146 \mathrm{Da}, \mathrm{H}_{\mathrm{f}}=-826 \mathrm{~kJ} / \mathrm{mol}$.

The precise $\frac{1}{2}$ mol fractions of $\mathrm{H}_{2} \mathrm{O}$ and $\mathrm{NH}_{3}$ in the peak at $\mathrm{T}_{\text {peak }}=185{ }^{\circ} \mathrm{C}, \mathrm{H}_{\text {peak }}=-77 \mathrm{~kJ} / \mathrm{mol}$, indicate that a dimer serves as intermediate step, $\gamma$-glutamylglutamine (Fig. 18a), $\mathrm{C}_{10} \mathrm{H}_{17} \mathrm{~N}_{3} \mathrm{O}_{6}$, chemspider 133013 , b.p. $596^{\circ} \mathrm{C}$ :

$$
2 \mathrm{Q}=\mathrm{C}_{10} \mathrm{H}_{20} \mathrm{~N}_{4} \mathrm{O}_{6} \longrightarrow\left[\mathrm{NH}_{3}+\mathrm{C}_{10} \mathrm{H}_{17} \mathrm{~N}_{3} \mathrm{O}_{6}\right] \text {. }
$$

After further ejection of $\mathrm{H}_{2} \mathrm{O}$ the total reaction is

$2 \mathrm{Q}=2\left(\mathrm{C}_{5} \mathrm{H}_{10} \mathrm{~N}_{2} \mathrm{O}_{3}\right) \longrightarrow \mathrm{NH}_{3}+\mathrm{H}_{2} \mathrm{O}+\mathrm{C}_{10} \mathrm{H}_{15} \mathrm{~N}_{3} \mathrm{O}_{5}$.

The database ChemSpider [9] lists for the residue a suitable molecule, 9185807, 5-Oxo-L-prolyl-L-glutamine (Fig. 18b), $\mathrm{C}_{10} \mathrm{H}_{15} \mathrm{~N}_{3} \mathrm{O}_{5}, 257 \mathrm{Da}$, b.p. $81{ }^{\circ} \mathrm{C}, \mathrm{H}_{\text {vap }}=$ $129 \mathrm{~kJ} / \mathrm{mol}$. Above the peak at $185^{\circ} \mathrm{C}$ optical observations show indeed a nonboiling liquid, agreeing with the high boiling point quoted.

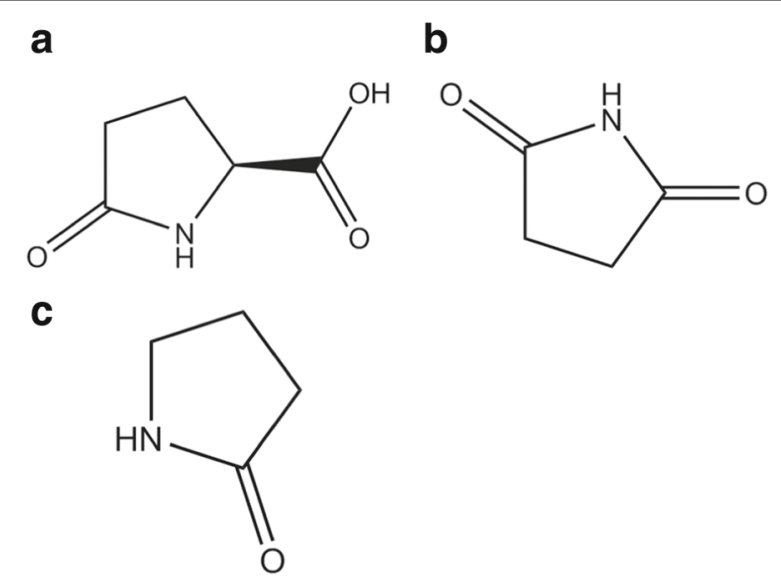

Fig. 17 Interpretation of Glutamate data. a, The final residue of $\mathrm{Glu}$, pyroglutamic acid, $\mathrm{C}_{5} \mathrm{H}_{7} \mathrm{NO}_{3}, 129 \mathrm{Da}$. b, Succinimide, $\mathrm{C}_{4} \mathrm{H}_{5} \mathrm{NO}_{2}, 99 \mathrm{Da}$. c, Pyrrolidone, $\mathrm{C}_{4} \mathrm{H}_{7} \mathrm{NO}, 85 \mathrm{Da}$

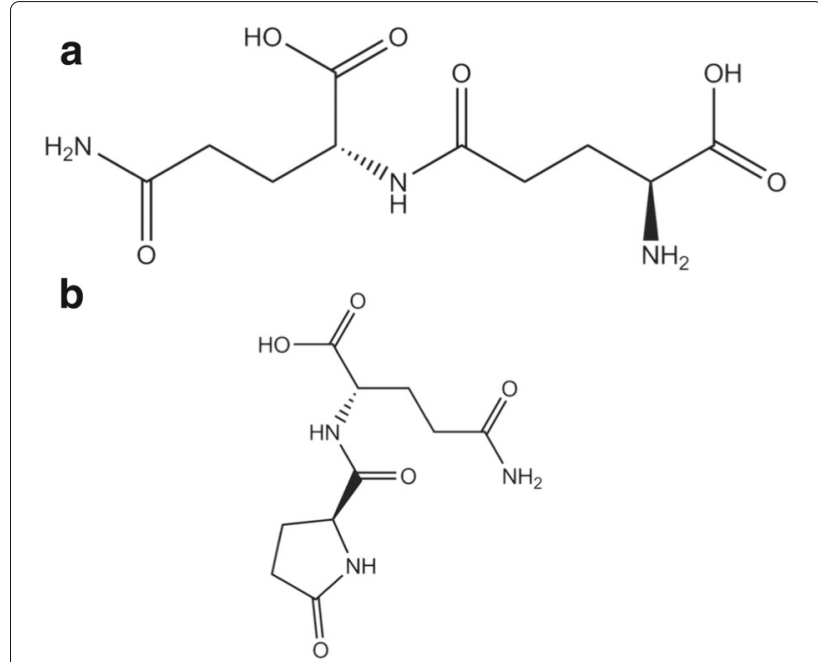

Fig. 18 Interpretation of Glutamine data. a, Intermediate step, gamma-glutamylglutamine, $\mathrm{C}_{10} \mathrm{H}_{17} \mathrm{~N}_{3} \mathrm{O}_{6}, 275 \mathrm{Da}$. $\mathbf{b}$, The residue of Gln: 5-Oxo-L-prolyl-L-glutamine, $\mathrm{C}_{1} \mathrm{OH}_{1} 5 \mathrm{~N}_{3} \mathrm{O}_{5}, 257 \mathrm{Da}$

\section{Arginine}

Arginine, Arg, R, $\mathrm{C}_{6} \mathrm{H}_{14} \mathrm{~N}_{4} \mathrm{O}_{2}: 174 \mathrm{Da}, \mathrm{H}_{\mathrm{f}}=-623 \mathrm{~kJ} / \mathrm{mol}$.

A small peak without mass loss at $220{ }^{\circ} \mathrm{C},-14 \mathrm{~kJ} / \mathrm{mol}$, and a main peak at $230{ }^{\circ} \mathrm{C},-52 \mathrm{~kJ} / \mathrm{mol}$, producing $1 \mathrm{~mol}$ $\mathrm{NH}_{3}$ plus $1 \mathrm{~mol} \mathrm{H}_{2} \mathrm{O}$ in QMS, confirmed by the weight loss of $20 \%$ of $174 \mathrm{Da}$ in TGA. The precursor peak without mass loss at $220{ }^{\circ} \mathrm{C},-14 \mathrm{~kJ} / \mathrm{mol}$, probably comes from a rearrangement in the guanidine star. In the large peak a double internal cyclization occurs. The loss of the amino group $-\mathrm{NH}_{2}$ in the backbone, and internal cycling joining the $\mathrm{N}$ next to the $\mathrm{C}^{\delta}$ in the side chain to $\mathrm{C}^{\alpha}$,

$$
\mathrm{C}_{6} \mathrm{H}_{14} \mathrm{~N}_{4} \mathrm{O}_{2} \longrightarrow \mathrm{NH}_{3}+\mathrm{H}_{2} \mathrm{O}+\mathrm{C}_{6} \mathrm{H}_{11} \mathrm{~N}_{3} \mathrm{O}_{2} .
$$

forms an intermediate, 1-Carbamimidoylproline, $157 \mathrm{Da}$, chemspider 478133 (Fig. 19a). It is called "..proline", because the ring is spanned between an $\mathrm{N}$ and $\mathrm{C}^{\alpha}$, though the $\mathrm{N}$ is not from the backbone. By losing the $-\mathrm{OH}$ and a second inner cyclization joining the

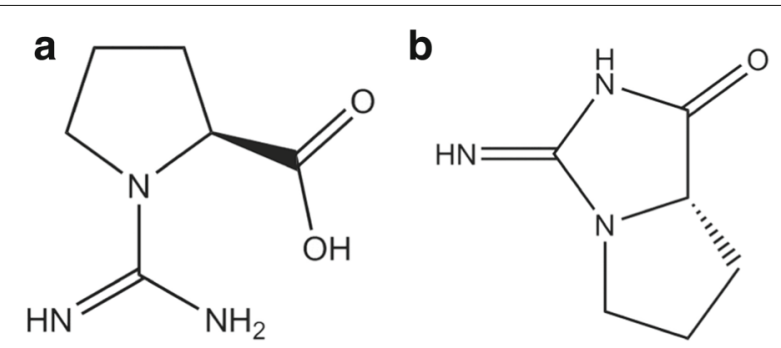

Fig. 19 Interpretation of Arginine data. a, 1-Carbamimidoylproline, $157 \mathrm{Da}$, representing the intermediate step after ejection of $\mathrm{NH}_{3}$ from Arg. b, The final residue of $\mathrm{Arg}_{1} \mathrm{C}_{6} \mathrm{H}_{9} \mathrm{~N}_{3} \mathrm{O}, 139 \mathrm{Da}$, "creatine-proline". The creatine ring on top joins the proline ring 
$=\mathrm{NH}$ or the $-\mathrm{NH}_{2}$ to $\mathrm{C}^{*}$, one or the other tautomer of the final residue is formed. The total reaction is $\mathrm{C}_{6} \mathrm{H}_{14} \mathrm{~N}_{4} \mathrm{O}_{2} \longrightarrow \mathrm{NH}_{3}+\mathrm{H}_{2} \mathrm{O}+\mathrm{C}_{6} \mathrm{H}_{9} \mathrm{~N}_{3} \mathrm{O}$, drawn in Fig. 19b, not quoted in the database $[9,14]$.

This final residue is remarkable. It contains the proline ring, the guanidine star and a peptide bond in the ring of creatinine, which is the 5-ring with the $=\mathrm{O}$ and $=\mathrm{OH}$ double bonds. Creatinine, $\mathrm{H}_{\mathrm{f}}=-240 \mathrm{~kJ} / \mathrm{mol}$, m.p. $300{ }^{\circ} \mathrm{C}$, $\mathrm{C}_{4} \mathrm{H}_{7} \mathrm{~N}_{3} \mathrm{O}$, chemspider 568 , has several tautomeric forms. The end product in question might contain either of those rings. We have no way to decide between the alternatives, but a double ring structure seems likely.

\section{Histidine}

Histidine, His, $\mathrm{H}, \mathrm{C}_{6} \mathrm{H}_{9} \mathrm{~N}_{3} \mathrm{O}_{2}: 155 \mathrm{Da}, \mathrm{H}_{\mathrm{f}}=-466 \mathrm{~kJ} / \mathrm{mol}$.

The QMS results are clear, His ejects $1 \mathrm{~mol} \mathrm{H}_{2} \mathrm{O}$ in the reaction

$$
\text { His }=\mathrm{C}_{6} \mathrm{H}_{9} \mathrm{~N}_{3} \mathrm{O}_{2} \longrightarrow 1 \mathrm{H}_{2} \mathrm{O}+\mathrm{C}_{6} \mathrm{H}_{7} \mathrm{~N}_{3} \mathrm{O} \text {. }
$$

The observed $1 \mathrm{~mol}_{2} \mathrm{O} / \mathrm{mol}$ His, confirmed by the weight loss of $13 \%$ of $155 \mathrm{Da}$, could stem from the condensation reaction of polymerization, but the volatility seen optically contradicts this option. Inner cyclization seems likely. If the $\mathrm{C}^{*}$ of the backbone joins the $\mathrm{C}$ of the imidazole ring, with $=\mathrm{O}$ and $-\mathrm{NH}_{2}$ attached outside, the 5-ring formed joins the 5-ring of the imidazole. The proposed structure is shown in Fig. 20.

The MolPort database [14] quotes this structure, but with the pyrazole ring (where the two $\mathrm{N}$ are nearest neighbours) instead of the imidazole ring (where the two $\mathrm{N}$ are next nearest neighbours): 5 -amino- $4 \mathrm{H}, 5 \mathrm{H}, 6 \mathrm{H}-$ pyrrolo[1,2-b]pyrazol-4-one, molport 022-469-240. Parting the nitrogens is energetically favorable: for pyrazole $\mathrm{H}_{\mathrm{f}}(\mathrm{s})=+105 \mathrm{~kJ} / \mathrm{mol}, \mathrm{H}_{\mathrm{f}}(\mathrm{g})=+179 \mathrm{~kJ} / \mathrm{mol}$; for imidazole $\mathrm{H}_{\mathrm{f}}(\mathrm{s})=+49 \mathrm{~kJ} / \mathrm{mol}, \mathrm{H}_{\mathrm{f}}(\mathrm{g})=+132.9 \mathrm{~kJ} / \mathrm{mol}$ [8]. Moreover,

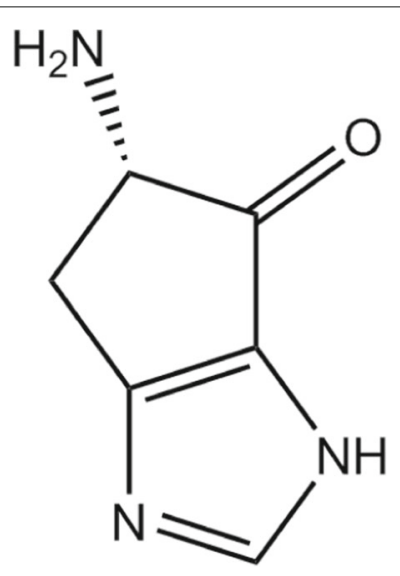

Fig. 20 Interpretation of Histidine data. Final residue of $\mathrm{His}, \mathrm{C}_{6} \mathrm{H}_{9} \mathrm{~N}_{3} \mathrm{O}$, $139 \mathrm{Da}$, consisting of two 5-rings: 2-amino-2,4-cyclopentadien-1-one $\left(\mathrm{C}_{5} \mathrm{H}_{5} \mathrm{NO}\right.$, chemspider 28719770) and imidazole the original His has an imidazole and not a pyrazole ring, and so does the residue.

\section{Discussion}

\section{Entropy of decomposition}

In the tables of Domalski [15], Chickos and Acree [16] and Acree and Chickos [17], at temperatures coinciding with our peak temperatures, "Heats of sublimation" of the order of our endothermic peak areas are reported. Our QMS signals prove that chemical decomposition is involved, but that should have been obvious from the DSC data alone. The average of the entropies of transformation, $S_{\text {peak }}=\mathrm{H}_{\text {peak }} / \mathrm{T}_{\text {peak }}$, is $215 \mathrm{~J} / \mathrm{Kmol}$, way above the usual entropies of melting $(22 \mathrm{~J} / \mathrm{kmol}$ for $\mathrm{H}_{2} \mathrm{O}, 28$ for $\mathrm{NaCl}, 36$ for $\mathrm{C}_{6} \mathrm{H}_{6}$ ), and higher than typical entropies of evaporation $\left(41 \mathrm{~J} / \mathrm{Kmol}\right.$ for $\mathrm{H}_{2} \mathrm{O}, 29$ for $\mathrm{CS}_{2}, 23$ for $\mathrm{CO}_{2}, 21$ for $\mathrm{NH}_{3}$ ). The endothermic heats in the peaks are therefore neither enthalpies of fusion nor enthalpies of sublimation, they are heats of reaction accompanied by phase changes. There is transformation and decomposition, but no reversible melting. Amino acids are stable in solid form, but not as liquids or gases.

\section{Peptide bond formation}

Five of the eight amino acids have residues containing peptide bonds, $-\mathrm{C}(=\mathrm{O})-\mathrm{NH}-$, only Asp and Asn leave polysuccinimide (PSI), Cys leaves cyclic pyrrolines. The preponderance of water in thermal decomposition is not surprising. In natural protein formation, each participating amino acid suffers damage. In the condensation reaction, where the $\mathrm{N}$-terminus of one molecule reacts with the $\mathrm{C}$-terminus of its neighbour, the planar peptide bond $-\mathrm{C} \alpha-\mathrm{CO}-\mathrm{N}-\mathrm{C} \alpha-$ is formed. The $\mathrm{N}$-atoms on, and the keto-bound $\mathrm{O}$-atoms off the backbones retain their position. $\mathrm{H}_{2} \mathrm{O}$ is ejected, but neither $\mathrm{NH}_{3}$ nor $\mathrm{CO}_{2}$ are produced in protein formation. Thermal decomposition of amino acids is analogous. In protein formation, the endothermic heat is provided by ATP, in amino acid decomposition it is thermal energy. Figure 21 summarizes the results.

\section{Peak areas}

Quantitatively, the parallel between protein formation and pyrolysis is confirmed on the enthalpy level. In the formation of a dipeptide, $\mathrm{X}+\mathrm{Y} \longrightarrow \mathrm{H}_{2} \mathrm{O}+(\mathrm{X}-\mathrm{Y})$, the difference between the enthalpies of the reactants and the products go into the formation of the peptide bond $(\mathrm{PB}): \mathrm{H}_{\mathrm{f}}(\mathrm{X})+\mathrm{H}_{\mathrm{f}}(\mathrm{Y})=-242 \mathrm{~kJ}+\mathrm{H}_{\mathrm{f}}(\mathrm{X}-\mathrm{Y})+\mathrm{H}_{\mathrm{PB}}$. With the tabulated value $[8,15]$ for $\mathrm{H}_{\mathrm{f}}(\mathrm{X}), \mathrm{H}_{\mathrm{f}}(\mathrm{Y})$ and $\mathrm{H}_{\mathrm{f}}(\mathrm{X}-\mathrm{Y})$ one calculates $\mathrm{H}_{\mathrm{PB}}=-67 \mathrm{~kJ}$ in glycylglycine, $-70 \mathrm{~kJ}$ in alanylglycine, $-43 \mathrm{~kJ}$ in serylserin, $-78 \mathrm{~kJ}$ in glycylvaline, $-65 \mathrm{~kJ}$ in leucylglycine, $-91 / 2 \mathrm{~kJ}$ in triglycylglycine, $-86 / 2 \mathrm{~kJ}$ in leucylglycylglycine, and $-58 \mathrm{~kJ}$ in 
glycylphenylalanine. The average value is $-59 \pm 13 \mathrm{~kJ}$ per peptide bond. The narrow standard deviation indicates that the enthalpy of forming a peptide bond is insensitive to its environment, therefore the endothermic values of oligomerization or polymerization should be close to this. One concludes that the formation of a peptide bond in a linear dimer is endothermic with an enthalpy of 59 $\pm 13 \mathrm{~kJ}$. It is tempting to compare this with the areas of the DSC peak, the observed endothermic heat of the decomposition reaction. The average of the eight amino acids is $-105 \pm 27 \mathrm{~kJ} / \mathrm{mol}$. One concludes that essentially the endothermic heat of decomposition, the peak area, goes into peptide bond formation.

\section{Production of $\mathrm{NH}_{3}$}

In cases where the $\mathrm{N}$-terminus, untouched by the condensation, remains attached to a cyclic product, it could be cut off as $\mathrm{NH}_{3}$, contributing up to $\frac{1}{2} \mathrm{~mol} \mathrm{NH} \mathrm{NH}_{3} / \mathrm{mol}$ AA. Remarkable is the absence of methane $\left(\mathrm{CH}_{4}, 16\right.$ $\mathrm{Da})$, hydrogen cyanide $(\mathrm{HCN}, 27 \mathrm{Da})$ and formamide
$\left(\mathrm{CH}_{3} \mathrm{NO}, 45 \mathrm{Da}\right)$, all in mass channels where we would have seen them. These, suspected in prebiotic synthesis of amino acids, do not appear in their decomposition. Although at most only three molecules are involved, two gases and one monomolecular residue, identification of the structure of the latter is not unequivocal, there remain more or less probable other possibilities than our choices. Clearly, without QMS, data from DSC and TGA could not possibly suffice to identify decomposition chains.

\section{Water, cyclic compounds and peptide bonds}

The novel quantitative results emphasize the importance of water and cyclic condensates containing peptide bonds. All postulated residues are cyclic compounds, five of the 8 contain peptide bonds. The residues are stable at temperatures $>180{ }^{\circ} \mathrm{C}$ and beyond the respective peak termperatures. These facts put constraints on hypothetical origin, state and stability of amino acids in the range between $200{ }^{\circ} \mathrm{C}$ and $300{ }^{\circ} \mathrm{C}$ in the absence and presence of water,

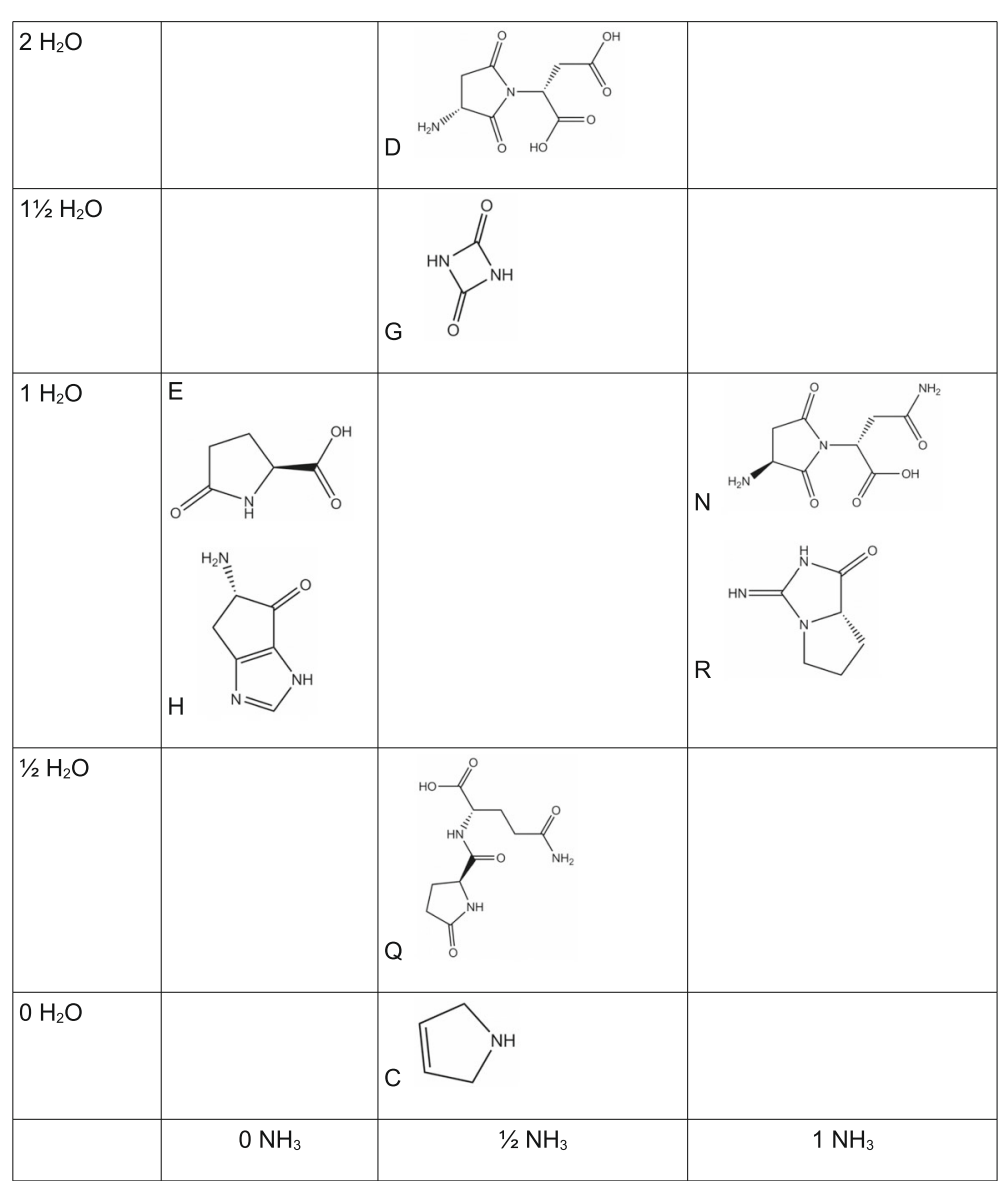

Fig. 21 Overview of the residues with respect to $\mathrm{H}_{2} \mathrm{O}$ or $\mathrm{NH}_{3}$ contents. All residues are obtained by ejection of $0, \frac{1}{2}, 1,1 \frac{1}{2}$ or 2 mols of $\mathrm{H}_{2} \mathrm{O}$ or $\mathrm{NH}_{3}$, placing them on two axes. All residues contain either $0, \frac{1}{2}$ or $1 \mathrm{~mol} \mathrm{NH}_{3}$ or $\mathrm{H}_{2} \mathrm{O}$, placing them on two axes. Most of them contain peptide bonds. The polysuccinimide of $\mathrm{D}$ and $\mathrm{N}$ is an exception, cysteine, for lack of oxygen, the other 
but literature is sparse in that respect. The history of diketopiperazine and derivatives is extensively reviewed by Prasad [18] back until 1888, the synthesis of cyclo-Gly-Gly by Curtius and Gloebel [19], but Prasad emphasized the relevance of these compounds as a class of natural products no earlier than 1922 [20-22]. Today, CDPs are recognized as "transkingdom signaling molecules" [23], indicating highly conserved mechanisms from earliest stages of life on earth. The potential of CDPs and related substances as novel drugs for biomedical applicatons is comprehensively reviewed by Borthwick [24], though he does not cover aqueous regimes above $150{ }^{\circ} \mathrm{C}$. Thermal formation of cyclo-Leu-Leu from the Leu-Leu dipeptide in the solid state was reported to occur at $177^{\circ} \mathrm{C}[25]$ - actually several month after the release of QMS data for amino acids Gly, Cys, Asp, Asn, Glu, Gln, Arg, and His in the solid state [26]. There might be differences in terms of thermal cyclization by dehydration, depending on whether or not the origin is an amino acid crystal or a dipeptide. Controlled biosynthesis of CDP by highly conserved enzymes is found in all domains of life [27]. However, the biochemistry of cyclo-dipeptides and related enzymatic pathways is a comparatively unexplored interdisciplinary field, usually based on genome analyses. Just recently, their presence in extremophilic organisms has been highlighted in more detail $[28,29]$. Previously reported evidences along with the first conclusive demonstration of thermal cyclization of Gly, Cys, Asp, Asn, Glu, Gln, Arg, and His by QMS, DSC and TGA as reported here put emphasis on the fact that cyclic dipeptides or cyclic compounds could represent thermally more stable precursors of prebiotic life.

\section{Conclusions}

Our comparative analysis allowed us to identify the eight of the twenty standard amino acids, for which the thermochemical equations unequivocally agree with stoichiometric release of $\mathrm{NH}_{3}, \mathrm{H}_{2} \mathrm{O}$ and $\mathrm{CO}_{2}$. The predominance of the release of $\mathrm{H}_{2} \mathrm{O}$ during the process of decomposition instead of melting indicates a common principle of condensation and, depending on the individual properties of the respective intermediate products, subsequent decomposition of the condensation products. Comparative data for all 20 standard amino acids, obtained by complementing DSC and TGA with quantitative mass spectrometry (QMS), have never been reported. For the eight with data closure we can say: Amino acids decompose thermally, they do not sublimate, nor do they melt. Only three gases are formed, mostly $\mathrm{H}_{2} \mathrm{O}$, less so $\mathrm{NH}_{3}$ and hardly any $\mathrm{CO}_{2}$. Cys forms $\mathrm{H}_{2} \mathrm{~S}$, but not $\mathrm{CS}_{2}$. In all amino acids investigated, Gly, Cys, Asn, Asp, Gln, Glu, Arg, His, the liquid or solid residues are lactams and heterocyclic compounds with 5- or 6-membered non- (or only partially) aromatic rings, containing one or two nitrogen atoms (pyrrolidines, piperidines, pyrrazolidines, piperazines ), most of them with peptide bonds present.

In summary, this work addresses an important question of amino acid thermal stability. Several processes may occur upon heating, chemical decomposition or sublimation/evaporation without decomposition. The aim of this work was to accurately determine these processes. For 8 out of the 20 standard amino acid, we demonstrated that these have a well defined temperature of decomposition. The contemporary detection of products of $17 \mathrm{Da}, 18 \mathrm{Da}$, and $44 \mathrm{Da}$ in the gas phase is the proof for decomposition, concise mass and enthalpy balances do not leave any room for speculation. Analysis and interpretation rule out the existence of any byproduct hydrocarbons which could not have been validated. The analysis for glycine, cysteine, aspartic acid, asparagine, glutamic acid, glutamine, arginine and histidine is beyond any doubt. At a heating rate of $5 \mathrm{~K} / \mathrm{min}$, neither melting nor sublimation take place. At least 8 of 20 standard amino acids do not exist in liquid form.

\section{Acknowledgements}

The authors thank Angela Rutz and Frederik Schweiger for technical assistance. This work would have been impossible without the continuous support of Eduard Arzt.

\section{Funding}

Not applicable.

Availability of data and materials

The datasets used and/or analysed during the current study are available from the corresponding author on reasonable request.

\section{Authors' contributions \\ IMW and HOKK designed the study, analyzed and interpreted the data and wrote the manuscript. CM prepared the samples and performed the visual examination of the amino acids. RD prepared the samples and performed the thermal analyses and quantitative mass spectrometry experiments. All authors read and approved the final manuscript.}

\section{Ethics approval and consent to participate}

Not applicable.

\section{Consent for publication}

Not applicable.

\section{Competing interests}

The authors declare that they have no competing interests.

\section{Publisher's Note}

Springer Nature remains neutral with regard to jurisdictional claims in published maps and institutional affiliations.

Received: 30 July 2017 Accepted: 2 January 2018

Published online: 09 February 2018

References

1. Nelson DL, Cox MM. Lehninger Principles of Biochemistry. New York: Macmillan; 2017.

2. Boldyreva E. Crystalline amino acids. In: Boeyens JCA, Ogilvie JF, editors. Models, Mysteries and Magic of Molecules. Dordrecht: Springer; 2013. p. 167-92. 
3. Barret G. Chemistry and Biochemistry of the Amino Acids. Heidelberg: Springer; 1985.

4. Follmann $\mathrm{H}$, Brownson C. Darwin's warm little pond revisited: from molecules to the origin of life. Naturwissenschaften. 2009;96:1265-92.

5. Acree W, Chickos JS. Phase transition enthalpy measurements of organic and organometallic compounds. sublimation, vaporization and fusion enthalpies from 1880 to 2010. J Phys Chem Ref Data. 2010;39:043101.

6. Electron-Impact Cross Section Database. Gaithersburg: NIST; 2017. http:// physics.nist.gov/PhysRefData/ASD/ionEnergy.html. Accessed 18 Jan 2018.

7. Rodante F, Marrosu G, Catalani G. Thermal-analysis of some alpha-amino-acids with similar structures. Thermochim Acta. 1992;194: $197-213$.

8. Haynes W. Standard thermodynamic properties of chemical substances. In: Lewin RA, editor. CRC Handbook of Chemistry and Physics. Boca Raton: CRC Press, Taylor and Francis Group; 2013. p. 5.

9. ChemSpider Free Chemical Structure Database. Cambridge: Royal Society of Chemistry; 2017. http://www.chemspider.com/. Accessed 18 Jan 2018.

10. Banack SA, Metcalf JS, Jiang LY, Craighead D, llag LL, Cox PA. Cyanobacteria produce $\mathrm{n}$-(2-aminoethyl)glycine, a backbone for peptide nucleic acids which may have been the first genetic molecules for life on earth. PLOS ONE. 2012;7(11):49043.

11. Schiff H. Über polyaspartsäuren. Berichte der deutschen chemischen Gesellschaft. 1897;30:2449-59.

12. Haitinger L. Vorläufige mittheilung über glutaminsäure und pyrrol. Monatshefte für Chemie und verwandte Teile anderer Wissenschaften. 1882;3:228-9.

13. Mosqueira FG, Ramos-Bernal S, Negron-Mendoza A. Prebiotic thermal polymerization of crystals of amino acids via the diketopiperazine reaction. Biosystems. 2008;91:195-200.

14. MolPort Chemical Compound Database. Riga: MolPort; 2017. https:// www.molport.com/. Accessed 18 Jan 2018.

15. Domalski ES. Selected values of heats of combustion and heats of formation of organic compounds containing the elements $c, h, n, O, p$, and s. J Phys Chem Ref Data. 1972;1:221-77.

16. Chickos JS, Acree WE. Enthalpies of sublimation of organic and organometallic compounds. 1910-2001. J Phys Chem Ref Data. 2002;31: 537-698.

17. Acree WE, Chickos JS. Phase transition enthalpy measurements of organic and organometallic compounds. sublimation, vaporization and fusion enthalpies from 1880 to 2015. part 1. c1-c10. J Phys Chem Ref Data. 2016;45:3-10106314948363.

18. Prasad C. Bioactive cyclic dipeptides. Peptides. 1995;16:151-64.

19. Curtius T, Goebel F. Ueber glycocollaether. J F Praktische Chemie. 1888:37:150-81.

20. Fischer $\mathrm{E}$, Raske K. Beitrag zur stereochemie der 2, 5-diketopiperazine. In: Bergmann M, editor. Untersuchungen Über Aminosäuren, Polypeptide und Proteine II (1907-1919). Berlin Heidelberg: Springer; 1923. p. 279-94.

21. Aberhalden E, Komm E. The formation of diketopiperazines from polypeptides under various conditions. Z Physiol Chem. 1924;139:147-52.

22. Aberhalden $E$, Haas R. Further studies on the structure of proteins: Studies on the physical and chemical properties of 2,5-di-ketopiperazines. Z Physiol Chem. 1926;151:114-9.

23. Ortiz-Castro R, Díaz-Pérez C, Martínez-Trujillo M, del Río RE, Campos-García J, López-Bucio J. Transkingdom signaling based on bacterial cyclodipeptides with auxin activity in plants. Proc Nat Acad Sci U S A. 2011;108:7253-8.

24. Borthwick AD. 2,5-diketopiperazines: Synthesis, reactions, medicinal chemistry, and bioactive natural products. Chem Rev. 2012;112:3641-716.

25. Ziganshin MA, Safiullina AS, Gerasimov AV, Ziganshina SA, Klimovitski $A E$, Khayarov KR, Gorbatchuk W. Thermally induced self-assembly and cyclization of I-leucyl-I-leucine in solid state. J Phys Chem B. 2017;121: 8603-10.

26. bioRxiv. NY, USA: Cold Spring Harbor Laboratory; 2017. http://dx.doi.org/ 10.1101/119123. Accessed 18 Jan 2018.

27. Belin P, Moutiez M, Lautru S, Seguin J, Pernodet JL, Gondry M. The nonribosomal synthesis of diketopiperazines in trna-dependent cyclodipeptide synthase pathways. Nat Prod Rep. 2012;29:961-79.

28. Tommonaro G, Abbamondi GR, lodice C, Tait K, De Rosa S. Diketopiperazines produced by the halophilic archaeon, haloterrigena hispanica, activate ahl bioreporters. Microbial Ecol. 2012;63:490-5.

29. Charlesworth JC, Burns BP. Untapped resources: Biotechnological potential of peptides and secondary metabolites in archaea. Archaea. 2015;282035.

\section{Submit your next manuscript to BioMed Central and we will help you at every step:}

- We accept pre-submission inquiries

- Our selector tool helps you to find the most relevant journal

- We provide round the clock customer support

- Convenient online submission

- Thorough peer review

- Inclusion in PubMed and all major indexing services

- Maximum visibility for your research

Submit your manuscript at www.biomedcentral.com/submit 